\title{
Price Movements around Short Covering Trades ${ }^{*}$
}

\author{
Hyuk Choe, Professor, Seoul National University \\ Hyo-Jeong Lee ${ }^{* *}$, Associate Professor, Kwangwoon University
}

\begin{abstract}
$<$ Abstract $>$
Using reported large short position data from Korea stock market, we studied stock price movements around the short covering trades. We found a significant negative relationship between the short covering trades and the stock return on the previous five trading days. trading days. It means that short sellers engage in contrarian trading when they cover short positions. Short coverings are associated with positive returns on the trading day, confirming that there is a positive transient price impact at the coverings of large short positions. We also found that stock prices decline steadily in the 60 trading days following short coverings. This indicates that some short sellers are forced to prematurely close out their positions, thus suffering opportunity losses. Particularly, when a sudden surge in stock prices causes involuntary large-scale short coverings to occur in the short squeeze, the price impact gets larger and short sellers bear greater opportunity losses. This study sheds light on short selling strategies in practice and market stabilizing policies.
\end{abstract}

Keywords: Short Covering; Contrarian; Price Impact; Timing Ability; Short Squeeze JEL Classification: G10, G14

\footnotetext{
* The present research has been conducted by the Research Grant of Kwangwoon University in 2020. Choe is grateful to the financial support by the Institute of Management Research, Seoul National University.

** Corresponding Author. Address: Kwangwoon University 20 Kwangwoon-ro, Nowon-gu, Seoul, Korea 01897; E-mail: leehj@kw.ac.kr; Tel: +82-2-940-8262; Fax: +82-2-940-8181.
}

Received: December 11, 2020; Revised: January 28, 2021; Accepted: February 4, 2021 


\title{
공매상환거래 주변의 주가움직임에 관한 연구
}

\author{
최 혁 (서울대학교 교수) \\ 이 효 정 (광운대학교 부교수)**
}

\begin{abstract}
<요 약>
본 연구에서는 공매도보고제도에 의해 구축된 공매도 잔고자료를 활용하여 공매도 상환거래(short covering)가 직전 주식수익률과 어떠한 관계를 갖는지, 이후 주식수익률에 어떠한 영향을 미치는지를 개별주식 차원에서 살펴보았다. 분석결과, 직전 5 거래일 수익률이 낮을수록 공매상환거래가 활발히 일어나, 공매거래자들이 상환시에 (공매도시와 마찬가지로) 역추세 추종거래(contrarian trades)를 하는 것으로 나타났다. 상환거래일 당일과 직후에 유의미한 가격상승이 나타나, 공매포지션 청산에 따른 가격충격을 확인할 수 있었다. 상환일 이후 장기수익률은 음의 값을 보여, 공매도 투자자들이 고평가 해소시점을 포착해 적절한 시점에 공매포지션을 정리한다고 보기 어려웠다. 한편, 자본제약과 공매도 제약으로 인해 비자발적으로 발생한 대규모 상환거래(솟스퀴즈 추정거래)에서 더 큰 가격충격이 나타 나고, 공매도 투자자들이 더 큰 기회손실을 부담하는 것으로 나타났다. 이 연구는 한국주식시장에서 공매상환거래의 영향을 분석한 최초의 연구로, 향후 실무적으로 투자전략을 구축하거나 시장안정 정책을 수립하는데 시사점을 준다.
\end{abstract}

핵심 단어 : 공매상환거래, 역추세 추종거래, 가격충격, 솟스퀴즈, 정보거래

JEL 분류기호: G10, G14

* 이 논문은 2020년 광운대학교 교내학술연구비 지원에 의해 연구되었음. 최혁 교수는 서울대학교 경영연구소의 연구비 지원에 감사한다.

** 연락담당 저자. 주소: 서울특별시 노원구 광운로 20 광운대학교 경영대학 01897;

E-mail: leehj@kw.ac.kr; Tel: 02-940-8262; Fax: 02-940-8181. 


\section{1. 서론}

공매도는 현재 소유하지 않은 증권을 일정기간 빌려 매도하는 거래로, 증권을 보유하지 않은 투자자가 주가 하락을 예측하는 경우 주식을 빌려 현재가격에 매도한 후 예상대로 가격이 하락한 다음 낮은 가격에 매수하여 상환함으로써 차익을 얻는 투자전략으로 사용된다. 공매도는 미보유주식에 대한 매도를 가능하게 하기 때문에 시장에 유동성을 공급하고, 부정적인 정보를 주가에 신속히 반영시켜 시장의 가격발견기능을 높이는 것으로 인식되고 있다(Boehmer et al., 2008; Boehmer and Wu, 2012; Diether et al., 2009a; Engelberg et al., 2012).

한국주식시장에서는 무차입 공매도(naked short sales) ${ }^{1)}$ 가 금지되어 있기 때문에 일반 적인 공매도는 대주(대차)거래 ${ }^{2}$ 를 반드시 수반하게 된다. 따라서, 공매거래자는 두 개의 거래, 즉 대주(대차)거래를 통해 주식을 차입한 후 공매도하는 거래(short selling)와 주식 시장에서 해당 주식을 환매수(short covering)하여 대주(대차) 포지션을 종결하는 거래를 마쳐야 비로서 공매포지션을 종결하고, 수익을 확정할 수 있다. 그럼에도 불구하고 선행 연구는 공매거래에만 초점을 맞추어 왔으며 ${ }^{3)}$ 상환거래에 관한 연구는 활발하지 않았다. 최근 실무분석가들에 의해 공매잔고가 많은 종목이 일정기간 후 환매수 유입으로 주가상승 가능성이 있음을 분석한 연구 ${ }^{4}$ 가 이루어졌지만, 공매도 상환거래에 대한 학문적인 연구는 활발하지 않았다. 그 이유는 종목별 또는 계좌별로, 일별 또는 일중 공매거래를 집계한 자료는 존재하지만,5) 상환거래를 집계한 데이터가 없었기 때문이었다, 상환거래는 각국 증권거래소 (NYSE, NASDAQ 등)가 제공하는 월별 공매잔고 또는 데이터제공업체(Data Explolers 등)가 제공하는 주 단위 대차잔고를 이용해 월별 또는 주별 상환량을 간접 추정하는 방식으로 파악하거나 특정증권사가 독점 제공한 고객거래자료를 토대로 파악되었다. ${ }^{6)}$ 한국시장에서도

1) 공매도는 빌리지 않은 상태에서 먼저 매도를 하고 결제일 $(\mathrm{T}+2)$ 전까지 매도한 증권을 빌려서 결제하는 무차입 공매도 방식과 증권을 먼저 차입한 뒤 매도하는 차입공매도 방식으로 나누어진다. 무차입공매도는 2000년 3월 우풍상호신용금고가 성도이엔지 주식을 공매도한 후 결제하지 못하는 사건을 계기로 2000년 6월부터 결제의 안정성이 담보되는 경우에 한하여 허용되고 있다.

2) 대주거래는 개인투자자가 증권사에 요청하여 한국증권금융 등을 거쳐 주식을 빌리는 것을 말하고, 대차거래는 기관투자자나 외국인투자자가 한국예탁결제원이나 한국증권금융을 통해 주식을 빌리는 것을 말한다.

3) 공매거래에 관한 연구로는 Dechow et al., 2001; Diether et al., 2009a, 2009b; Diamond and Verrecchia, 1987; Boehmer and Wu, 2012; Beber and Pagano, 2013; Asquith et al., 2005; Christophe et al., 2004, 2010; Kim and Lee, 2013; Eom, 2012; Choe and Lee, 2012 등이 있다.

4) 신한금융투자, 2019, ‘숏이 너무 많다’; 한국투자증권, 2019, ‘공매도 숏커버링 가능성 점검’; 하나 금융투자, 2019, ‘중장기는 고배당주, 트레이딩은 솟커버 종목으로 시장을 이긴다’.

5) Christophe et al.(2004), Dask et al.(2005), Diether et al.(2009a), Boehmer et al.(2008) 등이 사용하였다.

6) Liu and Xu(2016), Savor and Gamboa-Cavazos(2011), Massa and Beschwitz(2015) 등이 사용 하였다. 
Price Movements around Short Covering Trades

자본시장법에 따라 공매도 시에는 동 호가가 공매도임을 밝혀야 하기 때문에 일별 공매 현황을 파악할 수 있지만, 상환매수 시에는 상환매수임을 밝히지 않아도 되기 때문에 환매 현황은 파악하기가 어려웠다.

최근 들어 각국에서 공매도 거래의 투명성 제고 등을 목적으로 공매도잔고 보고 및 공시 제도를 도입함에 따라 이것을 활용해 숏커버링 자료를 구축할 수 있게 되었고, 공매도 상환 거래에 관한 연구가 진행되고 있다. Boehmer et al.(2018)이 동경주식거래소(TSE)의 공매도 잔고 공시자료를 분석해 환매거래일 주변의 주가움직임을 연구했고, Woo and Kim(2019)이 한국주식거래소(KSE)의 공매잔고 보고자료를 이용해 공매도 전략의 투자성과를 분석했다. Jones et al.(2016)과 Jank et al.(2021)은 각각 UK·프랑스-스페인과 독일의 대규모 공매도 잔고 공시자료를 분석해 공매잔고 공시규제가 공매활동에 미치는 영향을 살펴보았다. 이 연장선상에서 본 연구는 2016년 6월 30일부터 2020년 3월 13일까지 공매도잔고 보고 제도에 따라 유가증권시장과 코스닥시장에서 공매잔고를 보고한 종목-거래일 표본을 이용해 공매상환거래가 직전거래일 주가와 어떠한 관계를 갖는지, 상환거래일 당일에 가격충격이 발생하는지, 이후 장기주가가 하락하는지를 연구하였다. 일별, 종목별로 제공되는 공매도 잔고 데이터셋을 이용하여 종목별로 $\mathrm{T}-1$ 일 공매도잔고에서 $\mathrm{T}$ 일 공매도잔고를 뺀 다음 발행주식수로 나누어 일별 공매상환비율( $\Delta \mathrm{SIR})$ 을 산출해 상환거래 현황을 파악하였다.

먼저, 이 연구에서는 상환거래와 직전수익률 간의 관계를 분석하여 공매거래자가 역추세 추종거래(contrarian trades)를 하는지를 살펴본다. 선행연구(Diether et al., 2009b; Blau et al., 2012)에서는 공매량과 과거수익률의 관계를 분석하여 공매거래자들이 역추세 추종 거래를 함을 발견하였고, 이를 근거로 공매도가 고평가된 주식을 본질가치로 회귀시키는 역할을 수행한다고 주장하였다. 만약, 공매거래자가 상환시에도 주가하락 후 환매수하는 역추세 추종거래를 한다면, 상환거래도 시장안정 기능을 한다고 볼 수 있을 것이다. 아울러 이것은 행태주의 재무학(Behavioral Finance) 관점에서도 흥미로운 주제이다. 만약 공매 거래자가 상환시에 역추세 추종거래를 한다면, 주가하락으로 이익을 본 포지션은 빨리 처분하며 주가상승으로 손실을 본 포지션은 계속 보유한다고 볼 수도 있다. 이는 공매거래자가 비록 정보거래자로 알려졌음에도, 행태적 편의인 처분효과(disposition effect) ${ }^{7)}$ 의 영향을 받는 다는 간접적인 증거라고 판단된다. ${ }^{8)}$

7) Shefrin and Statman(1985)은 투자자들이 이익을 본 종목을 빨리 팔고, 손실을 본 종목을 계속 보유하려는 행태적 편의를 발견하고 이를 ‘처분효과(disposition effect)'라고 명명하였다. 이후 많 은 실증연구(Odean, 1998; Grinblatt and Keloharju, 2001; Grinblatt and Han, 2005)에서 개인투 자자가 처분효과의 영향을 받는다는 증거가 보고되었다.

8) 처분효과를 엄밀하게 입증하기 위해서는 직전수익률이 아니라, 포지션의 손익을 추정하여 이것과 상환거래와의 관계를 입증해야 한다. 실제로 Massa and Beschwitz(2015)는 Grinblatt and Han (2005)의 방식으로 공매거래자의 자본이득(capital gain)을 추정하여, 공매 이후 주가하락으로 추정 자본이득이 커질수록 공매포지션 상환이 증가함을 보이고, 정보거래자로 알려진 공매거래자도 처분 효과의 영향을 받는다고 주장하였다. 
한국증권학회지 제 50 권 1호 (2021)

다음으로, 이 연구에서는 상환거래 당일의 가격충격과 이후의 주가움직임을 분석해 한국 시장에서의 상환거래를 정보거래로 볼 수 있는지를 규명하고자 한다. 공매 시에는 업틱룰 (uptick-rule)에 따른 비용, 차입증권에 대한 담보비용, 대주(대차) 수수료 등이 발생하기 때문에, 이것을 부담하고 공매를 하려는 투자자는 향후 주가움직임에 대한 사적 정보 (private information)를 보유한 정보거래자일 가능성이 높다. 실제로 공매도가 주가하락을 예측한다는 증거가 실증연구(Boehmer et al., 2008; Diether et al., 2009b; Engelberg et al., 2012)에서 보고되었다. 공매자가 정보거래자라면 해당 주식이 고평가된 시점을 포착해 공매할 뿐만 아니라, 고평가가 해소되거나 새로운 정보유입으로 해당 주식이 저평가 상태로 바뀐 시점을 포착해 공매포지션을 청산할 것으로 기대할 수 있다. 이 경우, 공매 후 주가가 하락하는 것과 마찬가지로 환매수 후 주가가 상승하는 현상이 관찰될 것이다. 그러나, 공매자가 고평가된 주식을 선별해 공매포지션을 형성하였음에도 불구하고 이후 해당 주식의 가격이 예상과 반대로 상승할 수 있다(Lamont and Stein, 2004; Jarrow, 1992; Stambaugh et al., 2012). 가격이 불리하게 움직일 때 추가비용 없이 포지션을 유지할 수 있는 매수거래와 달리, 공매거래는 포지션 유지를 위해 추가담보를 제공해야 하고, 해당 종목이 포트폴리오 에서 차지하는 비중이 커지는 부담에 노출되기 때문에 비자발적으로 포지션을 청산하는 경우가 발생한다(Jarrow, 1992; Savor and Gamboa-Cavazos, 2011). 공매자가 외부환경 (마진콜, 주식대여만기도래 등)에 의해 포지션을 조기 상환한다면, 상환시점에 일시적 가격 충격이 있더라도 일정기간이 지나면 남아있던 가격 괴리가 해소되면서 주가가 지속적으로 하락할 것이다.

마지막으로 공매도 상환거래 중 정보거래로 추정되는 것과 솟스퀴즈 거래로 추정되는 것을 골라 각 유형별로 상환거래 이후 주가움직임을 비교 분석한다. 상환매수 안에 고평가 해소여부를 적기에 파악해 이루어진 정보거래 성격의 상환과 자본제약 및 공매제약으로 인한 비자발적 상환, 헤지 목적의 포지션 종결을 위해 고평가 여부와 관계없이 행해지는 중립적 상환 등 이질적 유형의 거래가 혼재되어 있을 것이다. Boehmer et al.(2018)은 총 공매거래량과 포지션수익률을 이용해 정보거래 목적의 상환거래를 식별한 후 거래일 주변의 주가움직임을 분석했고, $\mathrm{Liu}$ and $\mathrm{Xu}(2016)$ 는 직전월의 가격상승률과 공매잔고비율이 높은 종목을 솟스퀴즈 종목으로 보고 이들 거래 이후의 주가움직임을 분석했다. 이 연구에서도 상환거래 중 정보거래로 추정되는 것과 숏스퀴즈 거래로 추정되는 것을 골라 각각이 시장에 미치는 영향을 분석함으로써 공매도거래자의 투자행태와 영향력을 규명할 것이다.

주요 분석방법과 분석결과는 다음과 같다. 먼저, 상환거래가 발생한 종목-거래일 표본을 표본군으로 하고, 상환거래가 발생하지 않은 종목-거래일 표본을 대조군으로 하여 각각에 대해 상환거래일 직전, 당일, 직후의 누적초과수익률 $\left(C R_{[-5,-1]}, C A R_{[0,0]}, C A R_{[1,2]}, C A R_{[3,5]}, C A R_{[6,10]}\right)$ 을 분석하였다. 분석결과, 직전 5 거래일 누적초과수익률 $\left(C A R_{[-5,-1]}\right)$ 은 표본군에서는 음인 반면 대조군에서는 양으로 나타나, 공매자들이 주가하락시에 포지션을 상환하고 상승시 추가 
Price Movements around Short Covering Trades

공매함을 알 수 있었다. 상환거래일 당일과 직후의 초과수익률 $\left(C A R_{[0,0]}, C A R_{[1,2]}\right)$ 은 표본군에서 양수, 대조군에서 음수를 나타내, 일시적인 가격충격을 확인할 수 있었다. 상환거래 이후 $1 \sim 3$ 개월간의 초과수익률 $\left(C A R_{[1,20]}, C A R_{[1,60]}\right)$ 은 표본군과 대조군 모두가 음의 값을 보여 공매 거래는 수익률 예측력을 갖고 있지만, 상환거래는 그렇지 않음을 알 수 있었다. 상환일 주변의 주가움직임이 상환 강도와 관련이 있는지를 분석하기 위에서 공매상환비율 $(\Delta \mathrm{SIR})$ 에 따라 10 분위 등가중 포트폴리오(decile portfolios)를 구성해 상환일 전후의 누적 초과수익률을 분석하였다, 위와 유사하게 공매거래자들이 공매시뿐만 아니라 상환시에도 컨트래리안 거래를 하는 것으로 나타났고, 가격충격이 공매상환비율에 비례하는 것으로 분석되었으며, 공매 시에는 공매시점을 적절히 선택해 투자수익을 얻지만, 상환시에는 고평가 해소시점을 적절히 포착해 주가상승 직전에 공매포지션을 정리한다고 보기 어려웠다.

다음으로 직전일 공매도잔고 $\left(\operatorname{SIR}_{t-1}\right)$, 공매상환비율 $\left(\Delta \operatorname{SIR}_{t}\right)$, 직전주 수익률 $\left(C A R_{[-5,-1]}\right)$ 을 이용하여 패자 포트폴리오(Loser)와 승자 포트폴리오(Winner)를 구성한 후, 각 포트폴리오별 상환거래일 주변의 주가움직임을 비교 분석하였다. $S I R_{t-1}, \Delta \mathrm{SIR}_{t}, C A R_{[-5,-1]}$ 이 모두 상위 $10 \%$ 인 종목으로 구성된 패자 포트폴리오는 직전 5 거래일간 공매수익률이 나쁘지만, 공매잔고 부담이 커 비자발적으로 공매포지션을 청산한 종목(숏스퀴즈)으로 볼 수 있고, $\operatorname{SIR}_{t-1}$ 과 $\Delta \mathrm{SIR}_{t}$ 는 상 위 $10 \%$ 이지만, $C A R_{[-5,-1]}$ 이 하위 $10 \%$ 인 종목으로 구성된 승자 포트폴리오는 직전 공매수익 률이 좋고 공매잔고가 많아 차익을 실현한 종목(정보거래)으로 볼 수 있다. 분석결과, 패자 포트폴리오가 거래 당일 가격충격이 크고, 이후 장기수익률이 큰 것으로 나타나, 자본제약 과 공매제약으로 인해 비자발적으로 발생한 솟스퀴즈 종목에서 더 큰 가격충격이 나타나 고, 투자자들이 더 큰 기회손실을 입는 것을 확인할 수 있었다.

이 논문은 공매잔고비율 $0.01 \%$ 이상인 보고의무자의 공매잔고를 합산해 구축한 공매도 잔고 데이터를 활용하여 일별, 종목별로 공매상환 현황을 정확하게 파악했다는 점에서 기존 연구를 한 차원 발전시켰다. 선행연구는 월별 공매잔고 또는 주단위 대차잔고를 활용해 상환량을 간접 추정하다 보니 상환거래 현황을 정확히 파악하지 못했다. 공매도 공시제도를 활용해 일단위로 공매상환거래량을 파악한 연구(Boehmer et al., 2018)도 있었지만, 공시 의무발생 기준이 너무 높아(발행주식수의 $0.25 \%$ 이상) 일부 대규모 공매거래자의 활동만을 분석하는 한계가 있었다. 본 연구자가 조사한 바로는, 이 연구는 한국시장에서 공매상환 거래일 주변의 주가움직임을 실증분석한 최초의 연구이다. 여태까지 알려지지 않았던 공매 상환거래자의 성격과 이들이 주가에 미치는 영향을 밝힘으로써, 실무적으로 공매투자전략을 구축하거나 공매와 관련된 시장안정정책 등을 입안하는데 도움을 줄 것으로 기대한다.

논문의 구성은 아래와 같다. 제 2장에서는 공매 및 공매상환과 관련된 선행연구를 검토 하고, 제 3장에서는 공매상환 데이터셋이 어떻게 구축되었는지를 현행 공매도잔고 보고제도와 관련하여 소개하고, 표본 및 주요변수를 정의하였다. 제 4장에서는 상환거래일 주변의 주가 움직임에 대한 실증분석 결과를 제시하였다. 제 5장에서는 결과를 요약하고 시사점을 설명하였다. 


\section{2. 선행연구}

초창기 공매도에 관한 연구는 공매가 미래수익률을 예측하는지, 공매거래자가 정보거래자 인지를 규명하는데 초점을 맞추었다. Asquith and Meulbroek(1996)와 Desai et al.(2002)는 각각 NYSE·AMEX와 나스닥을 분석하여 공매잔고비율이 높은 주식이 이후 유의하게 낮은 초과수익률을 나타낸다는 것을 보여주었다. Diether et al.(2009b)은 공매거래자가 컨트래리안 거래를 하며, 미래의 주가하락을 예측함을 발견하고, 이들이 단기과열을 포착해 공매거래를 한다고 보았다. 한편, 공매도시 수반되는 거래비용을 감수하고 공매도를 하는 투자자들은 사적정보를 보유한 정보거래자일 수 있음을 보여주는 연구도 이루어졌다. Dechow et $\mathrm{al} .(2001)$ 은 공매투자자들이 상대가치비율 $(\mathrm{E} / \mathrm{P}, \mathrm{B} / \mathrm{P})$ 이 낮은 주식을 공매했다가 이 비율이 상승 반전할 때 공매포지션을 청산함을 보여주었고, Christophe et al.(2004)의 실적공시 직전 공매거래를 분석하여, 공매거래자가 실적공시 후 주가움직임을 예측하여 공매한다는 증거를 보고했다. Boehmer et al.(2008)은 대량 공매종목의 이후 20거래일 수익률이 유의하게 낮은 것으로 보아 공매거래자를 정보거래자로 볼 수 있고, 특히 기관투자자의 비프로그램 공매가 가장 정보력이 높다고 주장했다. Christophe et al.(2010)과 Eom(2012)은 각각 나스닥과 코스피 · 코스닥을 분석하여 애널리스트의 투자의견 하향 직전에 공매가 급증하는 경향이 있고, 공매가 많은 종목의 주가가 더 하락하였음을 보여주었다. Kim and Lee(2013)는 한국시장을 분석하여 투자주체별 공매수익을 추정하여 외국인이 다른 투자주체에 비해 유의하게 높은 공매수익을 얻었음을 보여주었다.

공매도가 시장의 유동성 및 가격발견기능을 개선하는지에 관한 연구도 이루어졌다. Boehmer and $\mathrm{Wu}(2012)$ 는 공매가 가격발견 기능을 높인다는 증거를 발견했고, Diether et al.(2009a)는 2005년 미국 SHO 규제를 분석해, 규제완화 이후 능동적 거래전략이 활발하게 이루어졌으나, 일별 주식수익률과 변동성에는 큰 변화가 없음을 보여주었다. Diamond and Verrecchia(1987)는 공매제약이 존재할 경우, 공매가 일반적인 매도에 비해 더 많은 정보를 함유하게 되어 공매 거래시 가격조정 속도가 빨라진다고 주장하였다. Beber and Pagano(2013), Boehmer et al.(2013), Boulton and Braga-Alves(2010)는 2008 금융위기시 단행된 공매도금지로 인해 시장의 유동성이 줄어들고, 스프레드 및 일중 변동성으로 측정한 시장의 질이 하락하였으며, 가격발견 기능이 저하되었음을 보여주었다. Choe and Lee(2012)는 한국시장의 공매규제를 분석해, 공매규제가 유동성과 시장의 질을 위축시키며, 이 같은 효과는 공매금지보다 공매 제한에서 더 크게 나타난다고 주장하였다.

한편, 숏커버링에 대한 연구는 월별 공매잔고 또는 주단위 대차잔고를 활용하거나, 최근 도입된 각국의 공매도잔고 보고 및 공시제도를 이용해 진행되었다. Massa and Beschwitz (2015)는 주단위 대차잔고를 분석하여 공매자가 자본이익이 큰 포지션을 더 많이 청산(환매수) 하는 경향을 발견하고 이것을 처분효과로 설명하였다. Savor and Gamboa-Cavazos(2011)는 
Price Movements around Short Covering Trades

공매거래자가 주가상승 후 숏커버링을, 주가하락 후 추가공매를 하며 이로 인해 투자손실을 입었음을 발견하고, 이를 근거로 정보거래자도 예상과 다른 시장움직임이 발생하면 투자 손실을 본다고 주장하였다. Boehmer et al.(2018)은 동경거래소(TSE)의 공매도잔고 공시 자료를 이용해 숏커버링 주변의 주가움직임을 연구하였다. 그들은 솟커버링이 발생한 당일과 직후에 가격이 상승함을 발견하였고, 이를 근거로 대형 공매거래자들이 사적정보와 시장 타이밍능력을 보유하고 있다고 주장했다.

공매 후 주가가 오히려 상승해 공매자가 투자손실을 입을 수 있음을 보여준 연구도 있었다. Lamont and Stein(2004)는 투자심리가 좋을 때 고평가된 주식이 더 상승할 수 있음을 보여 주었고, Jarrow(1992)는 투자심리가 좋을 때 대규모 매수로 일시적인 가격충격을 일으켜 투자수익을 얻으려 하는 투자자(manipulative traders)에 의해 공매투자자들이 포지션을 강제청산 해야 하는 상황에 처할 수 있음을 보여주었다. Stambaugh et al.(2012)도 투자 심리가 좋을 때, 공매포지션 유지비용 때문에 공매가 위축되어 비정상적인 주가수준이 오히려 심화될 수 있음을 보였다. 솟스퀴즈에 관한 연구는 Liu and Xu(2016), D'Avolio(2002) 등에 의해 진행되었다. Liu and $\mathrm{Xu}(2016)$ 는 솟스퀴즈가 발생하기 위해서는 자본제약(capital constrain)을 야기할 정도의 가격상승과 공매제약(short sale constraints)이 동시에 존재 해야 한다는 점에 착안해, 일별 수익률 $15 \%$ 이상이면서 월 단위 공매잔고비율 상위 $10 \%$ 이상인 종목으로 솟스퀴즈 표본을 구성하였다. 이들은 솟스퀴즈 당일 주가가 급등하고 이후 상당기간 하락함을 보여주면서 숏스퀴즈 시 포지션 강제청산 비용이 매우 크다는 것을 밝혔다. 한편, Boehmer et al.(2018)은 총 공매거래량과 직전수익률을 이용해 정보거래 성격의 상환 매수를 식별해 분석했고, 대형 공매자들이 사적정보와 시장타이밍능력을 보유하고 있음을 밝혔다.

한편, 투명성제고와 투자자보호 차원에서 도입한 공매도잔고 보고 및 공시 제도의 영향을 분석한 연구도 있다. Jones et al.(2016)은 UK-프랑스-스페인의 공매도잔고 공시제도를 분석하여 공시 후 음의 초과수익률과 다른 투자자에 의한 추종공매도가 발생함을 보이고 공시 및 보고제도가 시장불안정을 초래할 수 있다고 주장하였고, Jank et al.(2021)은 독일의 공매잔고 공시제도가 대규모 공매활동을 위축시켜 자산가격의 상향편의를 야기한다고 주장 하였다.

이 논문은 공매잔고비율 $0.01 \%$ 이상인 보고의무자의 공매잔고를 합산해 구축한 공매도 잔고데이터셋을 활용해 솟커버링 거래를 식별하고 솟커버링 주변의 주가움직임을 분석하였다. 월별 또는 주별 상환량을 간접 추정하거나, 일부 금융사 자료에 의존해 파악한 선행연구에 비해 일별 공매상환 현황을 정확하게 파악했다는 점에서 기존연구를 한 차원 발전시켰다. 특히 한국시장은 보고의무 발생 기준치가 비교적 낮아 공시의무 발생 기준치가 높은 일본 시장을 연구한 Boehmer et al.(2018)와 차별성을 갖는다. 


\section{3. 표본과 데이터}

\section{1 공매도잔고 보고제도와 상환거래자료}

이 연구에서는 공매도잔고 보고제도에 의해 파악된 대규모 공매잔고 보유자의 잔고 현황을 토대로 한국거래소에서 일별, 종목별로 구축한 공매도잔고 데이터셋을 활용하였다. 금융 당국은 공매도 거래의 투명성을 제고하고, 불공정 거래 등에 적시에 대응하기 위해 투자자 별로 주권상장법인 발행주식 총수에 대한 일별 공매도 순보유잔고 비율이 일정비율 이상이 되면 금융감독원과 한국거래소에 공매도잔고를 보고 또는 공시하는 제도를 두고 있다(<표 $1>$ 참고).

〈표 1〉 공매도 잔고보고 및 공시제도 개요

자본시장과 금융투자업에 관한 법률 시행령 제 208 조의 2 및 3 에 근거하여 마련한 공매도잔고보고 및 공시제도 규정의 개요이다. http://www.fss.or.kr/fss/kr/acro/nsp/report.jsp에서 상세내용을 확인할 수 있다.

\begin{tabular}{|c|c|c|}
\hline & 공매도잔고보고 & 공매도잔고공시 \\
\hline 의무발생기준 & $\begin{array}{l}\text { (1) 공매잔고비율이 } 0.01 \% \text { 이상이면서 } \\
\text { 잔고평가액이 } 1 \text { 억 원 이상* } \\
\text { (2) 잔고평가액 } 10 \text { 억 원 이상 }\end{array}$ & 공매도잔고비율 $0.5 \%$ 이상 \\
\hline & 주식명, 인적사항, 공매도잔고 등 & 주식명, 인적사항 고 \\
\hline 기한 및 주기 & $\begin{array}{l}\text { 의무발생기준에 도달한 날(보고의무발생 } \\
\text { 장종료 후 지체없이 보고 } \\
\text { 추가거래가 없어도 일별로 보고의무발생 } \\
\text { 발생 }\end{array}$ & $\begin{array}{l}\text { 일)로부터 } 2 \text { 영업일이 되는 증권시장의 } \\
\text { 기준 이상을 유지하면 매일 공시의무 }\end{array}$ \\
\hline 기타 & $\begin{array}{l}\text { ETF, ELW, DR 등을 제외하며 우선주, } \\
\text { 회기반시설 투융자회사 등이 발생한 주 }\end{array}$ & $\begin{array}{l}\text { 붇동산투자회사, 기업인수목적회사, 사 } \\
\text { 식은 포함함. }\end{array}$ \\
\hline
\end{tabular}

* 공매도잔고비율 $(\%)=\frac{\text { 공매도잔고 }}{\text { 상장주식수 }} \times 100$, 공매도잔고평가금액=공매도수량 $\times$ 당일종가

이에 따라, 공매도잔고비율이 $0.01 \%$ 이상이면서 공매도 잔고평가금액이 1 억 원 이상이거나 또는 잔고평가액이 10 억 원 이상인 투자자는 보고의무발생일로부터 2 영업일이 되는 날 증권시장의 장종료 후까지 인적 사항, 종목명, 보고의무발생일, 순보유잔고비율을 금융감독원에 보고하여야 하며, 이후 추가거래가 없어도 일별 보고의무발생기준 이상의 잔고를 유지할 경우 매일 잔고변동을 보고하여야 한다. 만약 보고의무를 이행하지 않을 경우 관련규정에 따라 과태료가 부과되기 때문에 이행의 강제성이 확보된다. 한국거래소에서는 이렇게 보고된 공매도잔고비율, 잔고수량, 잔고금액을 종목별로 합산하여 일별 공매도 잔고현황을 2016년 6 월 30일부터 제공하고 있다. 이 연구에서는 한국거래소에서 제공하는 일별, 종목별 공매도 잔고 데이터셋을 분석하였기 때문에 공매잔고비율이 $0.01 \%$ 이상이면서 잔고평가금액이 1 억 원이 넘거나, 잔고평가금액이 10 억 원 이상인 대규모 공매도거래자들의 공매활동을 
Price Movements around Short Covering Trades

연구대상으로 한다. 한편, 공매도잔고와 별도로 공매도거래량에 관한 자료도 한국거래소를 통해 수집하였다. 한국거래소에서는 공매도 거래시 그것이 '공매'임을 밝히도록 규정하고 있어 ${ }^{9)}$ 잔고비율(금액)이 일정수준 이상인 경우에만 집계되는 공매도잔고 자료(short interest data)와 달리, 공매도거래 자료(short trading data)에는 모든 공매도 거래내역이 기록되어 있다.

공매도잔고 데이터셋을 이용하여 각 잔고보고종목에 대해 거래일별 공매상환비율 $(\Delta \mathrm{SIR})$ 을 $\mathrm{T}-1$ 일 공매도잔고에서 T일 공매도잔고를 뺀 다음 발행주식수로 나누어 산출했다. 이 값이 양수면 해당일에 상환매수가 발생해 공매잔고가 감소했음을, 음수면 추가공매가 이루어져 공매잔고가 증가했음을 의미한다. 한편, 공매잔고비율(금액)이 일정기준 이하인 경우 보고 의무가 없어지기 때문에, 공매도잔고 데이터셋에는 불연속적인 부분이 존재한다. 이 경우, 공매잔고 전체가 상환되고, 전체가 새로 형성된 것으로 간주하여 공매상환비율을 파악하였다. 예를 들어, 동화약품이 2016년 10월 10일 공매잔고 25,433주(잔고비율 0.09\%)를 보고 하였다가, 11 12일에는 공매잔고를 보고하지 않고, 13 일에 공매잔고 15,518 주(잔고비율 $0.06 \%)$ 를 보고하였다. 이 경우, 11 일 공매포지션 전량이 상환된 것으로 $(\Delta \mathrm{SIR}=0.09 \%)$, 12 일은 결측치로 $(\Delta \mathrm{SIR}=\cdot), 13$ 일 전체 공매잔고가 새로 형성된 것으로 $(\Delta \mathrm{SIR}=-0.06 \%)$ 간주하여 상환데이터셋을 구축하였다. 실제로는 보고의무자별 공매잔고비율이 $0.01 \%$ 이하로 떨어졌을 뿐 공매포지션 전량이 상환(형성)되지 않았을 수 있기 때문에 11 일과 13 일의 공매상환비율이 과잉 추정되었을 가능성이 있다. 강건성 검증을 위해 불연속적인 거래일을 제외하고 실시한 분석에서도 동일한 결과가 도출되었다. 한편, 공매도잔고 데이터셋은 해당 종목에 대해 보고의무가 발생한 투자자의 공매잔고내역을 합산한 데이터이기 때문에, 각 종목별로 대규모 공매거래를 합산한 대표 투자자(representative investor)가 존재한다고 가정하고, 이 대표투자자가 각각의 거래일에 추가공매 또는 환매수를 하였는지를 나타내는 지표로 해석하여야 한다. ${ }^{10)}$

\section{2 표본의 구성}

본 연구에서는 현행 공매도잔고 보고제도가 시행된 2016년 6월 30일부터 코로나 팬데믹 으로 인해 공매도가 전면금지 되기 직전인 2020년 3월 13일까지 총 909거래일을 분석대상 기간으로 하였으며, 이 기간 동안 유가증권시장 및 코스닥시장에 상장된 종목 중 시장정보와 재무정보가 모두 존재하는 보통주를 분석대상 표본으로 하였다. 개별종목의 시장정보, 재무 정보는 키스밸류(KISVALUE)에서 구했다. 상장지수펀드(ETF), 주식워런트증권(ELW), 주식

9) 주식거래시 작성하는 매도유형코드에 매수 및 파생상품 거래의 경우 ‘ 0 '을, 일반매도의 경우 ' 1 '을, 차입증권매도의 경우 ' 2 '를, 미예탁주식매도의 경우 ‘ 6 '을 기록한다. 이 코드를 활용하여 해당거래가 공매도거래인지 여부를 파악할 수 있다.

10) 공매상환비율이 양수(음수)인 거래일에 해당종목에 대해 추가공매(환매수)를 한 투자자가 존재할 수 있다. 
예탁증서(DR)는 잔고보고의무 대상에서 제외되기 때문에 분석대상에서 제외하였고, 부동산 투자회사, 기업인수목적회사(SPEC), 사회기반시설 투·융자회사의 주식은 잔고보고의무 대상에 포함되기 때문에 분석대상에 포함하였다. 전체 표본종목 수는 유가증권시장 784 개, 코스닥 시장 1,296 개를 포함해 총 2,080 개이고, 표본종목이 공매도잔고를 보고한 거래일로 구성한 종목-거래일 표본수는 유가증권시장 437,112개, 코스닥시장 547,004개를 합쳐 총 984,116개 이다. 시장구조, 시장참가자의 성격이 상이할 수 있기 때문에 유가증권시장과 코스닥시장을 분리해 분석을 진행하였지만, 양 시장의 결과는 유사하였다.

\section{3 주요변수와 기술적 통계}

이 연구에서는 공매잔고비율(SIR), 공매상환비율( $\Delta S I R)$, 공매활동비율(STTR), 공매거래 비율(STOR)을 일별, 종목별로 산출하여 분석에 사용하였다. 공매잔고비율은 공매도잔고 보고제도에 따라 보고된 종목별 공매도잔고를 종목별 발행주식수로 나눈 비율이고, 공매 상환비율은 T-1일 공매도잔고에서 T일 공매도잔고를 뺀 값을 발행주식수로 나눈 비율이다. 공매활동비율과 공매거래비율은 종목별 공매도거래량을 각각 총거래량과 발행주식수로 나누어 산출하였다.

$$
\begin{aligned}
& \text { 공매잔고비율 }(\mathrm{SIR})_{\mathrm{i}, \mathrm{t}}=\frac{\text { 공매도잔고 }{ }_{\mathrm{i}, \mathrm{t}}}{\text { 상장주식수 }_{\mathrm{i}, \mathrm{t}}}
\end{aligned}
$$

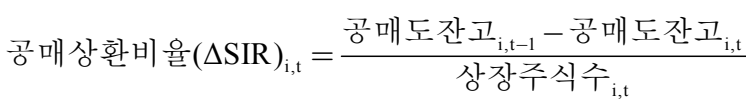

$$
\begin{aligned}
& \text { 공매활동비율 }(\mathrm{STTR})_{\mathrm{i}, \mathrm{t}}=\frac{\text { 공매도거래량 }{ }_{\mathrm{i}, \mathrm{t}}}{\text { 총거래량 }_{\mathrm{i}, \mathrm{t}}} \\
& \text { 공매거래비율 }(\mathrm{STOR})_{\mathrm{i}, \mathrm{t}}=\frac{\text { 공매도거래량 }{ }_{\mathrm{i}, \mathrm{t}}}{\text { 상장주식수 }_{\mathrm{i}, \mathrm{t}}}
\end{aligned}
$$

분석대상기간 동안 공매잔고비율과 공매활동비율의 시계열추이를 나타낸 <그림 1 >에서 알 수 있듯이, 공매잔고비율은 양 시장 모두에서 $0.7 \sim 1.0 \%$ 였고, 공매활동비율은 유가증권 시장(2 7\%)이 코스닥시장(0.5 3.5\%)보다 더 높았다. 코스닥시장 주식의 회전율이 높고 공매제한이 많기 때문에 이 같은 현상이 관찰된 것으로 보인다. 유가증권시장에서는 공매 잔고비율이 2017년 중반에 가장 높았다가 점차 감소하였고, 코스닥시장에서는 2018년 중반에 가장 높았으며, 이후 일시적으로 감소하다가 2019년 이후 다시 지속적으로 증가한 것으로 나타났다. 공매활동비율의 시계열추이는 양 시장에서 유사하게 관찰되었으며, 공매잔고비율에 비해 변동성이 컸다.

<표 2>와 <표 3> 패널 A에서 알 수 있듯이, 유가증권시장 표본 784개 중 72 개를 제외한 712 개 종목이, 코스닥 표본 1,296 개 중 156 개를 제외한 1,140 개 종목이 분석대상기간 중 
Price Movements around Short Covering Trades

1 회 이상 공매도잔고를 보고하였으며, 평균적으로 전체 909 거래일 중 유가증권시장 종목은 554.39 거래일에 코스닥 종목은 412.39거래일에 공매도잔고 보고를 한 것으로 나타났다. 대부분 종목에서 공매잔고비율이 발행주식총수의 $0.01 \%$ 이상이거나 잔고평가금액이 10 억 원 이상인 대규모 공매도거래잔고가 존재했으며, 분석대상기간 중 절반 이상에서 이 같은 공매잔고가 유지되었음을 알 수 있다.

〈그림 1〉 공매잔고비율과 공매활동비율의 시계열변동

분석대상기간인 2016년 6월 30일부터 2020년 3월 13일까지 공매잔고비율과 공매거래비율의 시계열변동을 나타낸 그림이다. 공매도잔고비율(SIR)은 공매도잔고 보고제도에 따라 보고된 종목별 공매도잔고를 발행주식수로 나누어 일별로 산출했고, 공매도거래량비율(STR)은 종목별 공매도 거래량을 총거래량으로 나누어 일별로 산출했다.

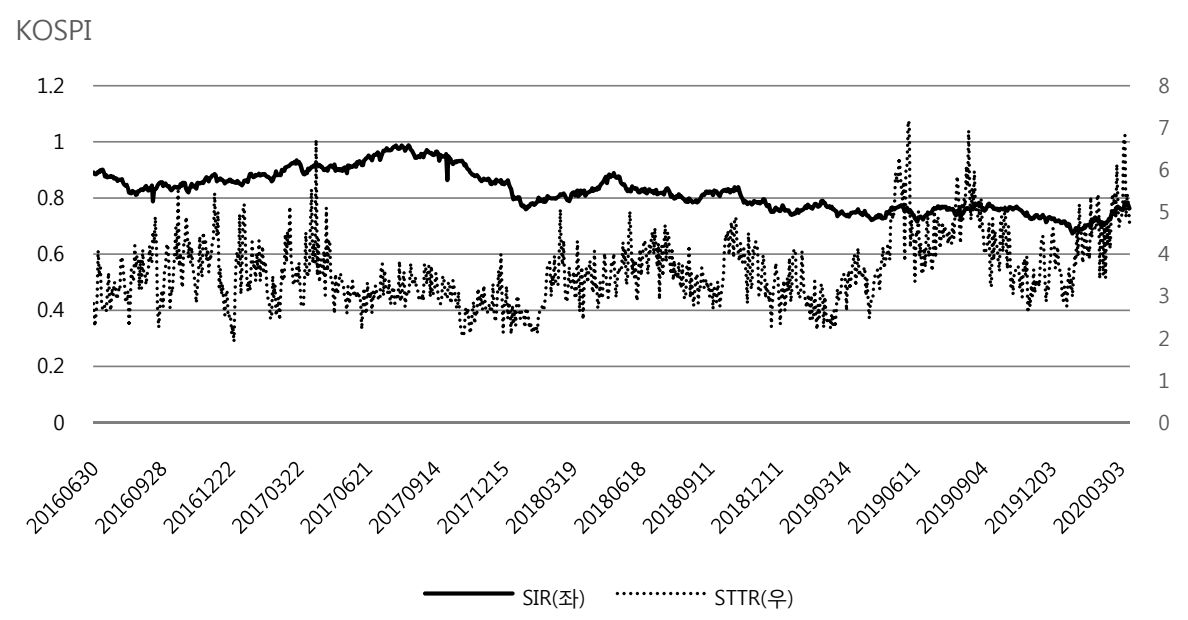

KOSDAQ

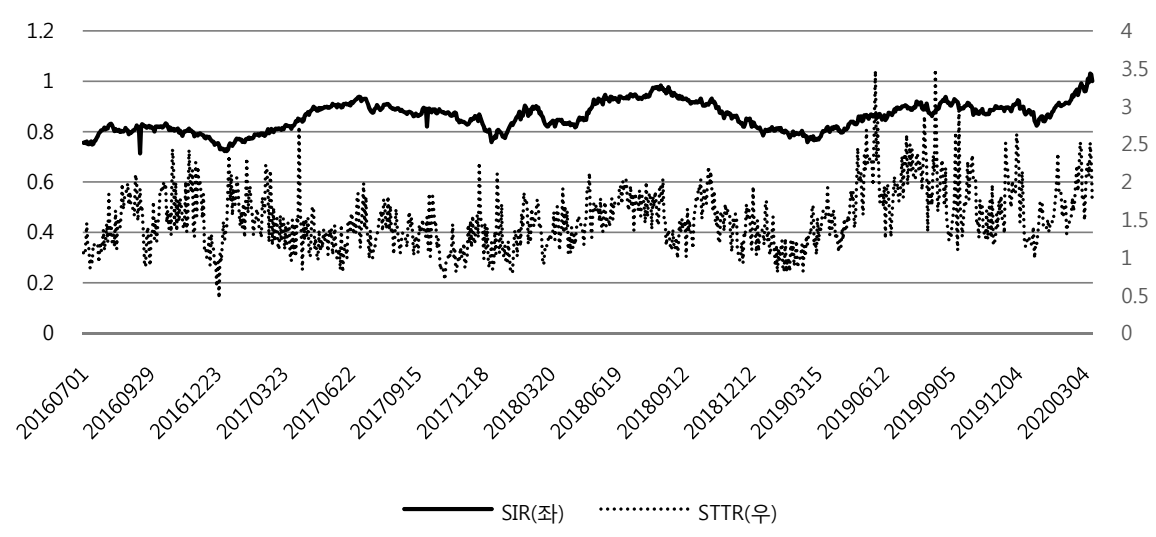


한국증권학회지 제 50 권 1호 (2021)

〈표 2〉공매도잔고 보고종목과 미보고종목의 기술통계량

표본기간 동안 공매도잔고 보고를 하지 않은 종목(non-reporting)과 잔고보고를 한 종목(reporting)의 공매도활동과 종목특성변수를 분석한 결과이다. 종목별로 각 변수의 시계열평균을 구한 후 보고종목군과 미보고종목군의 횡단면평균을 계산해 두 그룹 간의 평균값 차이를 T검정하였다. 공매도잔고비율(SIR), 공매활동비율(STTR), 공매거래비율(STOR), Amihud척도, 회전율(Turnover), 시장조정수익률(AR)은 일별로 산출했고, 기업규모(Size), 장부가치 대 시장가치 비율(BTM), 총변동성(Volatility)은 월별로 산출했다. SIR은 공매도잔고 보고제도에 따라 보고된 종목별 공매도잔고를 발행주식수로 나눈 비율이고, STTR과 STOR은 종목별 공매도거래량을 각각 총거래량과 발생주식수로 나눈 비율이다. Amihud는 수익률의 절대값을 해당일 거래대금으로 나눈 후 $10^{8}$ 을 해서 구했으며, Turnover는 거래량을 발행 주식수로 나누어 산출했다. VWAR은 종목별 수익률을 각각 KOSPI지수와 KOSDAQ지수의 수익률로 빼서 구했고, EWAR은 종목별 수익률을 해당시장소속 표본종목의 평균수익률로 빼서 산출했다. Size는 해당월말 시가총액을 자연로그한 값이고, BTM은 직전연도말 장부가치를 해당월말 시가총액으로 나눈 값이며, 변동성은 해당월 일별수익률의 표준편차이다. ${ }^{* * *}$ 는 $1 \%$ 유의수준에서, ${ }^{* *}$ 는 $5 \%$ 유의수준에서, *는 $10 \%$ 유의수준에서 통계적으로 유의함을 의미한다.

\begin{tabular}{|c|c|c|c|c|c|}
\hline \multirow{2}{*}{ Variable } & \multirow{2}{*}{ Class } & \multicolumn{2}{|c|}{ KOSPI } & \multicolumn{2}{|c|}{ KOSDAQ } \\
\hline & & $\mathrm{N}$ & Mean & $\mathrm{N}$ & Mean \\
\hline \multirow[t]{3}{*}{$\operatorname{SIR}(\%)$} & Non-reporting (0) & 72 & 0.000 & 156 & 0.000 \\
\hline & Reporting (1) & 712 & 0.664 & 1,140 & 0.624 \\
\hline & Diff $(0-1)$ & & $-0.664^{* * * *}$ & & $-0.624^{* * *}$ \\
\hline \multirow[t]{3}{*}{ STTR(\%) } & Non-reporting (0) & 72 & 0.345 & 156 & 0.087 \\
\hline & Reporting (1) & 712 & 3.939 & 1,140 & 1.591 \\
\hline & Diff $(0-1)$ & & $-3.595^{* * *}$ & & $-1.504^{* * *}$ \\
\hline \multirow[t]{3}{*}{ STOR(\%) } & Non-reporting (0) & 72 & 0.001 & 156 & 0.002 \\
\hline & Reporting (1) & 712 & 0.030 & 1,140 & 0.024 \\
\hline & Diff $(0-1)$ & & $-0.029^{* * *}$ & & $-0.022^{* * *}$ \\
\hline \multirow[t]{3}{*}{ Amihud } & Non-reporting (0) & 72 & 6.001 & 156 & 6.052 \\
\hline & Reporting (1) & 712 & 3.220 & 1,140 & 4.400 \\
\hline & Diff $(0-1)$ & & $2.781^{* * *}$ & & $1.652^{* * *}$ \\
\hline \multirow[t]{3}{*}{ BTM } & Non-reporting (0) & 72 & 2.279 & 156 & 1.474 \\
\hline & Reporting (1) & 712 & 2.040 & 1,140 & 1.030 \\
\hline & Diff $(0-1)$ & & 0.239 & & $0.444^{*}$ \\
\hline \multirow[t]{3}{*}{$\mathrm{FO}(\%)$} & Non-reporting (0) & 70 & 7.320 & 156 & 2.313 \\
\hline & Reporting (1) & 711 & 11.085 & 1,140 & 4.584 \\
\hline & Diff $(0-1)$ & & $-3.765^{* *}$ & & $-2.270^{* * * *}$ \\
\hline \multirow[t]{3}{*}{ Size } & Non-reporting (0) & 72 & 24.808 & 156 & 23.828 \\
\hline & Reporting (1) & 712 & 26.569 & 1,140 & 25.350 \\
\hline & Diff $(0-1)$ & & $-1.762^{* * *}$ & & $-1.522^{* * *}$ \\
\hline \multirow[t]{3}{*}{ Turnover $(\%)$} & Non-reporting (0) & 72 & 0.964 & 156 & 5.456 \\
\hline & Reporting (1) & 712 & 1.187 & 1,140 & 1.854 \\
\hline & Diff $(0-1)$ & & -0.223 & & $3.602^{* *}$ \\
\hline \multirow[t]{3}{*}{ Volatility } & Non-reporting (0) & 72 & 1.609 & 156 & 2.060 \\
\hline & Reporting (1) & 712 & 2.308 & 1,140 & 2.981 \\
\hline & Diff $(0-1)$ & & $-0.699^{* * *}$ & & $-0.921^{* * *}$ \\
\hline \multirow[t]{3}{*}{ VWAR } & Non-reporting (0) & 72 & -0.055 & 156 & -0.408 \\
\hline & Reporting (1) & 712 & -0.067 & 1,140 & -0.083 \\
\hline & Diff $(0-1)$ & & 0.012 & & $-0.326^{* *}$ \\
\hline \multirow[t]{3}{*}{ EWAR } & Non-reporting (0) & 72 & 0.017 & 156 & -0.048 \\
\hline & Reporting (1) & 712 & 0.002 & 1,140 & -0.012 \\
\hline & Diff $(0-1)$ & & $0.015^{* *}$ & & -0.037 \\
\hline
\end{tabular}


Price Movements around Short Covering Trades

〈표 3〉공매도잔고 상환거래일과 미상환거래일의 기술통계량

패널 $\mathrm{A}$ 는 표본기간 동안 표본종목이 공매도잔고 보고를 한 거래일과 그 중 상환거래 보고를 한 거래일의 분포를 나타낸다. 패널 $\mathrm{B}$ 는 각 종목별 공매도잔고보고일 표본을 다시 공매상환비율 $(\Delta \mathrm{SIR})$ 이 양수인 거래일(Covering)과 0 또는 음수인 거래일(Non-covering)로 분류하고, 두 그룹 각각에 대해 SIR, $\triangle$ SIR, STTR, STOR, Amihud, BTM, FO, TO, Volatility를 평균한 후, 두 그룹간 평균치의 차이를 T검정 (paired t-test)하였다. ${ }^{* * *}$ 는 $1 \%$ 유의수준에서, ${ }^{* *}$ 는 $5 \%$ 유의수준에서, ${ }^{*}$ 는 $10 \%$ 유의수준에서 통계적으로 유의함을 의미한다. 각 변수의 정의는 <표 2>와 동일하다.

패널 $\mathrm{A}$ : 공매도잔고 보고일수와 상환거래 보고일수

\begin{tabular}{lrrrrrcccccc}
\hline & \multirow{2}{*}{$N$} & \multicolumn{4}{c}{ 공매도잔고 보고일수 } & \multicolumn{4}{c}{ 상환거래 보고일수 } \\
\cline { 3 - 13 } & & Max & Mean & Med & Min & Std & Max & Mean & Med & Min & Std \\
\hline KOSPI & 784 & 909 & 554.39 & 648 & 0 & 343.43 & 522 & 277.14 & 306 & 1 & 159.91 \\
KOSDAQ & 1,296 & 908 & 412.39 & 365 & 0 & 335.45 & 535 & 208.70 & 180 & 0 & 155.24 \\
\hline
\end{tabular}

패널 $\mathrm{B}$ : 공매도잔고 상환보고일(Covering)과 미상환보고일(Non-covering)의 차이검정

\begin{tabular}{|c|c|c|c|c|c|}
\hline \multirow{2}{*}{ Variable } & \multirow{2}{*}{ Class } & \multicolumn{2}{|c|}{ KOSPI } & \multicolumn{2}{|c|}{ KOSDAQ } \\
\hline & & $\mathrm{N}$ & Mean & $\mathrm{N}$ & Mean \\
\hline \multirow[t]{3}{*}{$\overline{\operatorname{SIR}(\%)}$} & Non-covering (0) & 611 & 0.737 & 872 & 0.736 \\
\hline & Covering (1) & & 0.736 & & 0.750 \\
\hline & Diff $(0-1)$ & & -0.002 & & $-0.014^{* * *}$ \\
\hline \multirow[t]{3}{*}{$\Delta \operatorname{SIR}(\%)$} & Non-covering $(0)$ & 611 & -0.030 & 872 & -0.040 \\
\hline & Covering (1) & & 0.030 & & 0.040 \\
\hline & Diff $(0-1)$ & & $-0.060^{* * *}$ & & $-0.081^{* * *}$ \\
\hline \multirow[t]{3}{*}{$\operatorname{sTTR}(\%)$} & Non-covering $(0)$ & 611 & 5.991 & 872 & 2.993 \\
\hline & Covering (1) & & 3.253 & & 1.367 \\
\hline & Diff $(0-1)$ & & $2.729^{* * * *}$ & & $1.627^{* * * *}$ \\
\hline \multirow[t]{3}{*}{$\operatorname{STOR}(\%)$} & Non-covering $(0)$ & 611 & 0.050 & 872 & 0.046 \\
\hline & Covering (1) & & 0.020 & & 0.018 \\
\hline & Diff $(0-1)$ & & $0.029^{* * *}$ & & $0.028^{* * *}$ \\
\hline \multirow[t]{3}{*}{ Amihud } & Non-covering $(0)$ & 611 & 2.531 & 872 & 3.930 \\
\hline & Covering (1) & & 2.554 & & 3.997 \\
\hline & Diff $(0-1)$ & & -0.023 & & -0.067 \\
\hline \multirow[t]{3}{*}{ BTM } & Non-covering $(0)$ & 611 & 1.877 & 872 & 0.680 \\
\hline & Covering (1) & & 1.393 & & 0.665 \\
\hline & $\operatorname{Diff}(0-1)$ & & 0.486 & & $0.016^{* *}$ \\
\hline \multirow[t]{3}{*}{$\mathrm{FO}(\%)$} & Non-covering $(0)$ & 610 & 12.180 & 872 & 5.277 \\
\hline & Covering (1) & & 12.077 & & 5.254 \\
\hline & Diff $(0-1)$ & & $0.062^{* *}$ & & 0.023 \\
\hline \multirow[t]{3}{*}{ Size } & Non-covering $(0)$ & 611 & 26.817 & 872 & 25.646 \\
\hline & Covering (1) & & 26.822 & & 25.655 \\
\hline & Diff $(0-1)$ & & $-0.010^{* * *}$ & & $-0.009^{* * *}$ \\
\hline \multirow[t]{3}{*}{ Turnover $(\%)$} & Non-covering $(0)$ & 611 & 1.522 & 872 & 2.451 \\
\hline & Covering (1) & & 1.278 & & 1.801 \\
\hline & Diff $(0-1)$ & & $0.246^{* * *}$ & & $0.650^{* * *}$ \\
\hline \multirow[t]{3}{*}{ Volatility } & Non-covering (0) & 611 & 2.466 & 872 & 3.223 \\
\hline & Covering (1) & & 2.429 & & 3.139 \\
\hline & Diff $(0-1)$ & & $0.034^{* * *}$ & & $0.084^{* * * *}$ \\
\hline \multirow[t]{3}{*}{ VWAR } & Non-covering $(0)$ & 611 & -0.185 & 872 & -0.191 \\
\hline & Covering (1) & & 0.020 & & -0.015 \\
\hline & Diff $(0-1)$ & & $-0.203^{* * *}$ & & $-0.176^{* * *}$ \\
\hline \multirow[t]{3}{*}{ EWAR } & Non-covering $(0)$ & 611 & -0.068 & 872 & -0.062 \\
\hline & Covering (1) & & 0.038 & & 0.002 \\
\hline & $\operatorname{Diff}(0-1)$ & & $-0.103^{* * *}$ & & $-0.064^{* * *}$ \\
\hline
\end{tabular}


한국증권학회지 제 50 권 1호 (2021)

공매도잔고 보고를 한 종목군과 하지 않은 종목군의 공매활동과 종목특성변수를 비교하기 위해, 종목별로 각 변수의 시계열 평균을 구한 후 보고종목군과 미보고종목군의 횡단면 평균을 계산해 두 그룹 간의 평균값 차이를 T검정하였다. 분석결과, 보고종목군에서 공매 잔고비율(SIR)뿐만 아니라, 공매활동비율(STTR), 공매거래비율(STOR), 외국인지분율(FO)이 유의하게 높은 것으로 나타났다. 주식 대여가능종목, 대여기간 등의 차이로 인해 공매도의 약 $70 \%$ 가 외국인투자자에 의해 이루어지다 보니, 외국인지분율이 높은 종목에서 공매도가 활발하고 공매잔고도 많았다. ${ }^{11)}$ 한편, 보고군이 미보고군에 비해 Amihud 척도가 낮고, 회전율(Turnover)이 높은 것으로 나타나 대규모 공매잔고를 보고한 종목이 그렇지 않은 종목에 비해 유동성이 양호한 것으로 분석되었다. 보고군이 미보고군에 비해 기업규모 (Size)와 변동성(Volatility)이 유의하게 크고, 장부가치 대 시장가치비율(BTM)이 적은 것으로 나타나, 대규모 공매잔고를 보유한 공매투자자들이 기업규모와 수익률 변동성이 크면서 상대적으로 고평가된 성장주를 선호함을 알 수 있었다. 일평균 시장조정수익률은 두 그룹 간에 유의한 차이가 관찰되지 않았다. Amihud척도, 회전율, 시장조정수익률은 일별로 산출했고, 기업규모, 장부가치 대 시장가치 비율, 총변동성은 월별로 산출했다. 각 변수의 정의는 아래와 같다.

Amihud척도: (수익률의 절대값/거래대금) $\times 10^{8}$, 상위 $1 \%$ 극단값을 조정(winsorizing)해 산출

$\mathrm{BTM}$ (장부가치 대 시장가치비율): 직전 사업연도 말 자기자본총액/월말 시가총액

$\mathrm{FO}$ (외국인지분율): 직전연도 말 외국인 보유지분율

$\operatorname{SIZE}$ (기업규모): $\ln$ (월말 시가총액) $\ln$ (직전 사업연도 말 재무제표상 발행주식수 $\times$ 월말 주가)

Turnover(회전율): 일별거래량/발행주식수

Volatility(변동성): 해당 월 일별수익률의 표준편차

$\operatorname{VWAR}$ (가치가중 시장조정수익률): 종목수익률-코스피(코스닥)지수 수익률

$$
\left(V W A R_{i, t}=R_{i, t}-R_{\text {kospip (kosdaq }), t}\right)
$$

$\mathrm{EWAR}($ 등가중 시장조정수익률): 종목수익률-시장별 전체 표본의 평균 수익률

$$
\left(E W A R_{i, t}=R_{i, t}-\bar{R}_{i, t}\right)
$$

$C A R_{\left[t, t_{2}\right]}$ : 표본종목 전체로 구성된 등가중 포트폴리오의 수익률을 시장수익률로 사용해

11) 기관투자자와 외국인투자자는 한국예탁결제원과 한국증권금융을 통해 주식을 빌릴 수 있으며, 상장주식 전체를 만기 없이 대차할 수 있다. 반면, 개인투자자는 개별증권사를 통해 한국증권금융 으로부터 대주하여야 하고, 대주가능 종목이 한국증권금융이 제공하는 신용융자담보주식에 한정되어 있으며 만기가 최장 60일로 정해져 있다. 한국거래소에 따르면, 2018년 말 기준 전체 공매도거래 중 $67 \%$ 가 외국인 투자자에 의해, $32.1 \%$ 가 기관투자자에 의해 이루어진 것으로 분석 되었다(Woo and Kim, 2019). 
Price Movements around Short Covering Trades

각 종목의 일별 초과수익률을 구한 후, 이것을 해당 기간 동안 누적해 산출 $\left(C A R_{i,\left[t_{1}, t_{2}\right]}=\sum_{t=t_{1}}^{t=t_{2}} E_{i, t}\right)^{12)}$

한편, 상환거래일과 그렇지 않은 날의 공매활동과 주식특성변수 값에 차이가 있는지를 살펴보기 위해 각 종목별 잔고보고일 표본을 다시 공매상환비율 $(\Delta \mathrm{SIR})$ 이 양수인 거래일과 0 또는 음수인 거래일로 분류하였다. 〈표 3> 패널 $\mathrm{A}$ 에서 알 수 있듯이, 유가증권시장 종목은 공매도잔고 보고를 한 554.39일 중 277.14일에서, 코스닥종목은 412.39일 중 208.70일에서 공매잔고가 감소한 것으로 나타나, 잔고보고일 중 절반 정도에서 상환거래가 우세했음을 알 수 있었다, 종목별로 두 그룹 각각에 대해 각 변수를 평균한 후, 두 그룹간 평균치의 차이를 T검정(paired t-test)하였다. 표본기간 중 공매도잔고 보고를 한 거래일수가 50일 이하인 종목은 짝진 표본검정에 필요한 충분한 관측치가 확보되지 않아 분석에서 제외하였다. <표 3> 패널 $\mathrm{B}$ 에서 알 수 있듯이, 공매잔고비율(SIR)은 두 그룹 간에 큰 차이가 없었고, 공매상환비율( $\Delta \mathrm{SIR})$ 은 상환거래일에는 $0.03 \%(0.04 \%),{ }^{13)}$ 그렇지 않은 날에는 $-0.03 \%(-0.04 \%)$ 임을 알 수 있었다. 공매활동비율(STTR)과 공매거래비율(STOR)은 상환거래일이 그렇지 않은 날에 비해 유의하게 낮아, 추가공매가 일어날 때 보고의무자뿐만 아니라 일반투자자의 공매거래가 활발히 일어남을 알 수 있었다. 상환거래일이 그렇지 않은 날에 비해 회전율 (Turnover), 변동성(Volatility)이 적은 것으로 나타나 상환거래일보다 추가공매 거래일에 유동성이 크고, 변동성이 증가함을 알 수 있었다.

\section{4. 실증분석 결과}

\section{1 공매도 상환거래일 주변의 주가 움직임}

공매상환거래와 직전수익률 간의 관계를 분석하고, 상환거래가 해당 주식의 주가에 미치는 영향을 살펴보기 위해 상환거래일 주변의 공매활동과 주가움직임을 분석하였다. 상환거래가 발생한 종목-거래일 표본( $\Delta \mathrm{SIR}>0)$ 을 표본군으로 하고, 상환거래가 발생하지 않은 종목거래일 표본 $(\Delta \mathrm{SIR} \leq 0)$ 을 대조군으로 하여 각각에 대해 사건일의 공매도활동 $(\mathrm{SIR}, \Delta S I R$, $\mathrm{STOR})$ 과 상환거래일 직전, 당일, 직후의 누적초과수익률 $\left(C A R_{[-5,-1]}, C A R_{[0,0]}, C A R_{[1,2]}, C A R_{[3,5]}, C A R_{[6,10]}\right)$ 을 분석하였다. 표본군은 198,958 개(242,100개), 대조군은 238,154 개 (304,904개)로 구성되어, 전체적으로 상환거래를 보고하지 않은 표본수(543,058개)가 보고한 표본수(441,058개)보다 많았다. 표본군과 대조군 별로 각 변수 값을 평균하고, 두 그룹 변수 값에 유의한 차이가 있는지를 $\mathrm{T}$ 검정하였다.

12) 코스피지수와 코스닥지수 수익률을 각각 가치가중 시장포트폴리오 수익률의 대용치로 보고 이것을 이용해 누적초과수익률을 산출한 경우에도 거의 동일한 결과가 나타났다.

13) 유가증권시장 표본의 평균을 괄호 밖에, 코스닥시장 표본의 평균을 괄호안에 기재하였다. 
한국증권학회지 제 50 권 1호 (2021)

〈표 4〉공매도 상환거래일 주변의 공매활동과 주가움직임

상환거래가 발생한 종목-거래일표본 $(\Delta \mathrm{SIR}>0)$ 을 표본군으로 하고, 상환거래가 발생하지 않은 종목거래일표본 $(\Delta \mathrm{SIR} \leq 0)$ 을 대조군으로 하여 각각에 대해 사건일의 공매도활동(SIR, $\Delta S I R, \mathrm{STOR})$ 과 상환 거래일 주변의 누적초과수익률 $\left(C A R_{[-5,-1]}, C A R_{[0,0]}, C A R_{[1,2]}, C A R_{[3,5]}, C A R_{[6,10]}, C A R_{[1,20]}, C A R_{[1,60]}\right)$ 을 분석하였다. 누적초과수익률은 표본종목 전체로 구성된 등가중포트폴리오의 수익률을 시장수익률로 사용해 각 종목의 일별초과수익률을 구한 후, 이것을 해당 기간동안 누적해 산출했다. ${ }^{* * *}$ 는 $1 \%$ 유의수준에서, **는 $5 \%$ 유의수준에서, *는 $10 \%$ 유의수준에서 통계적으로 유의함을 의미한다.

\begin{tabular}{|c|c|c|c|c|c|c|c|}
\hline \multirow{2}{*}{ Variable } & \multirow{2}{*}{ Class } & \multicolumn{3}{|c|}{ KOSPI } & \multicolumn{3}{|c|}{ KOSDAQ } \\
\hline & & $\mathrm{N}$ & Mean & Probt & $\mathrm{N}$ & Mean & Probt \\
\hline \multirow[t]{3}{*}{$\overline{S I R}(\%)$} & 대조군(0) & 238,154 & 0.771 & & 304,904 & 0.815 & \\
\hline & 표본군(1) & 198,958 & 0.856 & & 242,100 & 0.896 & \\
\hline & $\operatorname{Diff}(0)-(1)$ & & -0.085 & $* * *$ & & -0.081 & $* * *$ \\
\hline \multirow[t]{3}{*}{$\Delta S I R(\%)$} & 대조군(0) & 238,154 & -0.026 & & 304,904 & -0.036 & \\
\hline & 표본군(1) & 198,958 & 0.032 & & 242,100 & 0.047 & \\
\hline & $\operatorname{Diff}(0)-(1)$ & & -0.059 & $* * *$ & & -0.084 & $* * *$ \\
\hline \multirow[t]{3}{*}{ STOR $(\%)$} & 대조군(0) & 238,154 & 0.036 & & 304,904 & 0.044 & \\
\hline & 표본군(1) & 198,958 & 0.019 & & 242,100 & 0.018 & \\
\hline & Diff (0)-(1) & & 0.017 & $* * *$ & & 0.026 & $* * *$ \\
\hline \multirow{3}{*}{$C A R_{[-5,-1]}$} & 대조군(0) & 237,825 & 0.292 & & 304,118 & 0.602 & \\
\hline & 표본군(1) & 198,678 & -0.340 & & 241,658 & -0.626 & \\
\hline & Diff (0)-(1) & & 0.632 & $* * *$ & & 1.228 & $* * *$ \\
\hline \multirow{3}{*}{$C A R_{[0,0]}$} & 대조군(0) & 238,070 & -0.087 & & 304,736 & -0.080 & \\
\hline & 표본군(1) & 198,927 & 0.075 & & 242,038 & 0.041 & \\
\hline & $\operatorname{Diff}(0)-(1)$ & & -0.162 & $* * *$ & & -0.121 & $* * *$ \\
\hline \multirow[t]{3}{*}{$C A R_{[1,2]}$} & 대조군(0) & 238,095 & -0.127 & & 304,700 & -0.244 & \\
\hline & 표본군(1) & 198,903 & 0.053 & & 241,922 & 0.089 & \\
\hline & $\operatorname{Diff}(0)-(1)$ & & -0.180 & $* * *$ & & -0.333 & $* * *$ \\
\hline \multirow{3}{*}{$C A R_{[3,5]}$} & 대조군(0) & 238,061 & -0.063 & & 304,567 & -0.173 & \\
\hline & 표본군(1) & 198,887 & -0.055 & & 241,863 & -0.078 & \\
\hline & $\operatorname{Diff}(0)-(1)$ & & -0.009 & & & -0.094 & $* * *$ \\
\hline \multirow{3}{*}{$C A R_{[6,10]}$} & 대조군(0) & 238,010 & -0.101 & & 304,304 & -0.194 & \\
\hline & 표본군(1) & 198,842 & -0.075 & & 241,725 & -0.171 & \\
\hline & Diff $(0)-(1)$ & & -0.026 & & & -0.024 & \\
\hline \multirow{3}{*}{$C A R_{[1,20]}$} & 대조군(0) & 237,548 & -0.438 & & 302,642 & -0.943 & \\
\hline & 표본군(1) & 198,441 & -0.269 & & 240,562 & -0.473 & \\
\hline & Diff $(0)-(1)$ & & -0.169 & $* * *$ & & -0.471 & $* * *$ \\
\hline \multirow{3}{*}{$C A R_{[1,60]}$} & 대조군(0) & 223,760 & -1.055 & & 282,170 & -2.187 & \\
\hline & 표본군(1) & 188,551 & -1.008 & & 226,307 & -1.619 & \\
\hline & $\operatorname{Diff}(0)-(1)$ & & -0.047 & & & -0.567 & $* * *$ \\
\hline
\end{tabular}

<표 4>에서 알 수 있듯이, 양 시장 모두에서 표본군의 공매잔고비율(SIR)이 대조군에 비해 유의하게 높아, 공매잔고가 많은 종목에서 상환거래가 많이 발생함을 알 수 있었다. 표본군의 공매잔고비율 대비 일평균 상환비율 $\left(\frac{\Delta S I R}{S I R}\right)$ 이 0.037(0.052)로 나타났다. 잔고보고 의무자들이 공매포지션을 분할 처분하거나, 보고의무자 집단 내에서 상환거래와 추가공매가 
Price Movements around Short Covering Trades

동시에 일어나면서 상쇄효과가 발생하여 공매잔고비율 대비 일평균 상환비율이 낮게 나타난 것으로 추정된다. 공매거래비율(STOR)은 대조군이 표본군보다 높아, 보고의무자에 의해 추가공매가 일어난 종목에서 보고의무자뿐만 아니라 일반투자자의 공매거래도 활발하게 이루어졌음을 알 수 있었다.

상환거래일 직전 5 거래일 동안 누적초과수익률 $\left(C A R_{[-5,-1]}\right)$ 이 표본군에서 $-0.340 \%(-0.626 \%)$, 대조군에서 $0.292 \%(0.602 \%)$ 로 나타나 공매잔고 보유자가 직전 주가가 하락하면 공매포지션을 상환하고, 상승하면 추가 공매하는 것으로 분석되었다. 이는 공매자가 공매시와 마찬가지로 (Diether et al., 2009b; Blau et al., 2012), 상환매수시에도 컨트래리안 거래를 함을 의미 한다. 또한 주가하락으로 이익을 본 포지션을 빨리 처분하고, 주가상승으로 손실을 본 포지션을 보유한다고 볼 수 있으므로 공매거래자가 행태적 편의인 처분효과의 영향을 받는다는 간접적인 증거가 될 수도 있다(Massa and Beschwitz, 2015). 한편, Boehmer et al.(2018)는 동경증권 거래소의 공매잔고비율이 $0.25 \%$ 이상인 대규모 공매거래자의 상환거래를 계좌별로 분석하여, 대규모 포지션을 보유한 공매거래자가 상환거래를 하기 직전에 주가가 상승했다는 결과를 보고해 본 연구의 결과와 상이했다.

사건일 당일의 초과수익률 $\left(C A R_{[0,0]}\right)$ 은 상환거래가 발생한 표본군에서 $0.075 \%(0.041 \%)$, 추가공매가 발생한 대조군에서 $-0.087 \%(-0.080 \%)$ 였으며, 차이가 통계적으로 유의했다. 대규모 공매잔고를 보유한 종목에서 상환매수가 일어날 때 일시적으로 주가가 상승하고, 추가공매가 일어날 때 주가가 하락함을 알 수 있었다. 발행주식 수 대비 거래량으로 계산한 일평균 회전율(유가증권시장 $2.20 \%$, 코스닥시장 $4.33 \%$ )과 비교할 때 일평균 상환거래비율 (유가증권시장 $0.032 \%$, 코스닥시장 $0.047 \%$ )이 크지 않지만, 상환거래가 가격충격을 갖는 것으로 보인다. 직후 2 거래일의 누적초과수익률 $\left(C A R_{[1,2]}\right)$ 도 표본군에서 양수(유가증권시장 $0.053 \%$, 코스닥시장 $0.089 \%$ ), 대조군에서 음수(유가증권시장 $-0.127 \%$, 코스닥시장 $-0.244 \%$ )로 나타났다. 이후의 누적초과수익률 $\left(C A R_{[3,5]}, C A R_{[6,10]}\right)$ 은 표본군과 대조군 모두에서 음수를 기록 했으며, 대조군에서 더 낮은 수익률이 관찰되었다. 환매수거래의 경우, 당일과 직후에 양의 가격반응이 일어나다가 이후 일정기간 동안 일시적 가격충격이 해소되는 것으로 보이며, 이 현상은 일시적 유동성 효과(Hasbrouck, 1991)로 설명된다. 반면, 추가공매의 경우 당일 음의 가격반응이 일어나고, 이후에도 가격이 지속적으로 하락했는데, 이는 공매거래자들이 사적 정보를 이용하여 과대평가된 주식을 선별하는 능력이 있기 때문에 공매 후 해당 주식수익률이 하락한다고 한 선행연구(Boehmer et al., 2008; Diether et al., 2009b; Engelberg et al., 2012)와 일치한다.

공매거래자가 상환거래시에도 사적정보 및 투자시점 선별능력(timing ability)을 갖고 있는지를 살펴보기 위해 사건일 이후 1,3 개월 동안의 누적초과수익률 $\left(C A R_{[1,20]}, C A R_{[1,60]}\right)$ 을 분석하였다. 공매거래자가 정보거래자라면, 해당 주식이 고평가된 시점을 포착해 공매포지션을 형성할 뿐만 아니라, 고평가가 해소되거나 새로운 정보유입으로 해당 주식이 저평가 상태로 바뀐 때를 포착하여 공매포지션을 청산할 것으로 기대할 수 있다. 이 경우, 공매도 후 주가가 
한국증권학회지 제 50 권 1호 (2021)

하락하는 것과 마찬가지로, 환매수 후 주가가 상승 또는 더 이상 하락하지 않는 현상이 관찰될 것이다. 그러나 공매거래자가 외부환경 등에 의해 공매포지션을 조기에 청산한다면, 상환거래 이후에도 주가가 추가로 하락할 수 있다. 예를 들어, 공매한 주식의 가격이 급등해 마진콜이 발생한 경우, 포지션 유지비용을 충당하기 위해 공매거래자는 비자발적으로 포지션의 전부 또는 일부를 청산하여야 한다. 이 경우 환매수 이후 해당 주식의 고평가가 해소되면서 주가가 하락하고, 공매거래자는 포지션 조기청산에 따른 기회손실을 부담하게 된다. 분석 결과, 표본군의 상환매수 후 1 개월과 3 개월 초과수익률 $\left(C A R_{[1,20]}, C A R_{[1,60]}\right)$ 은 각각 $-0.269 \%$ $(-0.473 \%),-1.008 \%(-1.619 \%)$ 였다. 공매포지션 청산 후, 주가가 추가로 하락한 것으로 보아 공매거래자가 상환매수시 정보거래를 하는 것으로 보기 어려웠다. 반면, 대조군의 $C A R_{[1,20]}$ 는 $-0.438 \%(-0.943 \%), C A R_{[1,60]}$ 는 $-1.055 \%(-2.187 \%)$ 로 나타나, 공매시에는 주가하락을 예측하는 정보거래를 한다는 사실을 확인할 수 있었다.

\section{2 상환거래비율 포트폴리오별 상환거래일 주변의 주가움직임}

이상에서 보고된 상환거래일 주변의 주가움직임이 상환거래 강도와 관련이 있는지를 분석 하기 위해 전체 종목-거래일 표본을 공매상환비율 $(\Delta \mathrm{SIR})$ 에 따라 정렬한 후 10 분위 등가중 포트폴리오를 구성하고 포트폴리오별로 공매활동과 사건일 전후의 누적초과수익률을 분석 하였다. <표 5>에서 알 수 있듯이, 공매상환비율이 가장 큰 포트폴리오(D10)의 $\Delta \mathrm{SIR}$ 평균은 $0.111 \%(0.155 \%)$, 가장 낮은 포트폴리오(D1)의 $\Delta$ SIR 평균은 $-0.124 \%(-0.172 \%)$ 로, 포트 폴리오별로 유의한 차이가 있었다. 다만, 현 공매보고제도 하에서는 일별 보고의무발생기준 이상의 잔고를 유지할 경우 추가거래가 없어도 매일 잔고변동을 보고하여야 하다 보니, $\Delta \mathrm{SIR}$ 값이 0 인 관측치가 많아 5 6분위 포트폴리오(D5 D6)에서는 유의한 차이를 확보할 수 없었다. 공매잔고비율(SIR)은 양 극단에서 큰 값을 갖는 U자 형태를 보여, 공매잔고가 많은 주식군에 기존 포지션 청산이 활발히 일어나는 종목과 추가포지션 축적이 활발히 일어 나는 종목이 동시에 존재함을 알 수 있었다. 공매잔고가 많은 주식은 대차(대주)거래에 제약이 있기 때문에 상환이 활발히 일어나기도 하고, 높은 공매잔고가 신호효과(signaling effect)를 일으켜 추가 공매가 활발히 일어나기도 하는 것으로 해석된다. 공매거래비율(STOR)은 D1이 높아 추가공매가 많이 발생한 포트폴리오에서 보고의무자뿐만 아니라, 일반투자자도 공매를 활발히 했음을 알 수 있었다. 한편, 공매거래비율은 D10에서도 큰 값을 보이고 있는데, D10의 공매잔고비율(SIR)이 크다 보니 신호효과가 발생해, 일반투자자들이 이들 종목에 대해 (상환매수를 하고 있는 공매보고자와 달리) 공매도를 활발히 한 것으로 보인다. ${ }^{14)}$

14) 공매도보고제도에 따르면, 보고의무자들은 의무발생일로부터 2 영업일이 되는 날 증권시장의 장 종료 후까지 보고하면 되기 때문에, 증권거래소에 게시되는 공매도잔고 정보는 당일 기준으로 2일전 내역까지 확인할 수 있다. 
Price Movements around Short Covering Trades

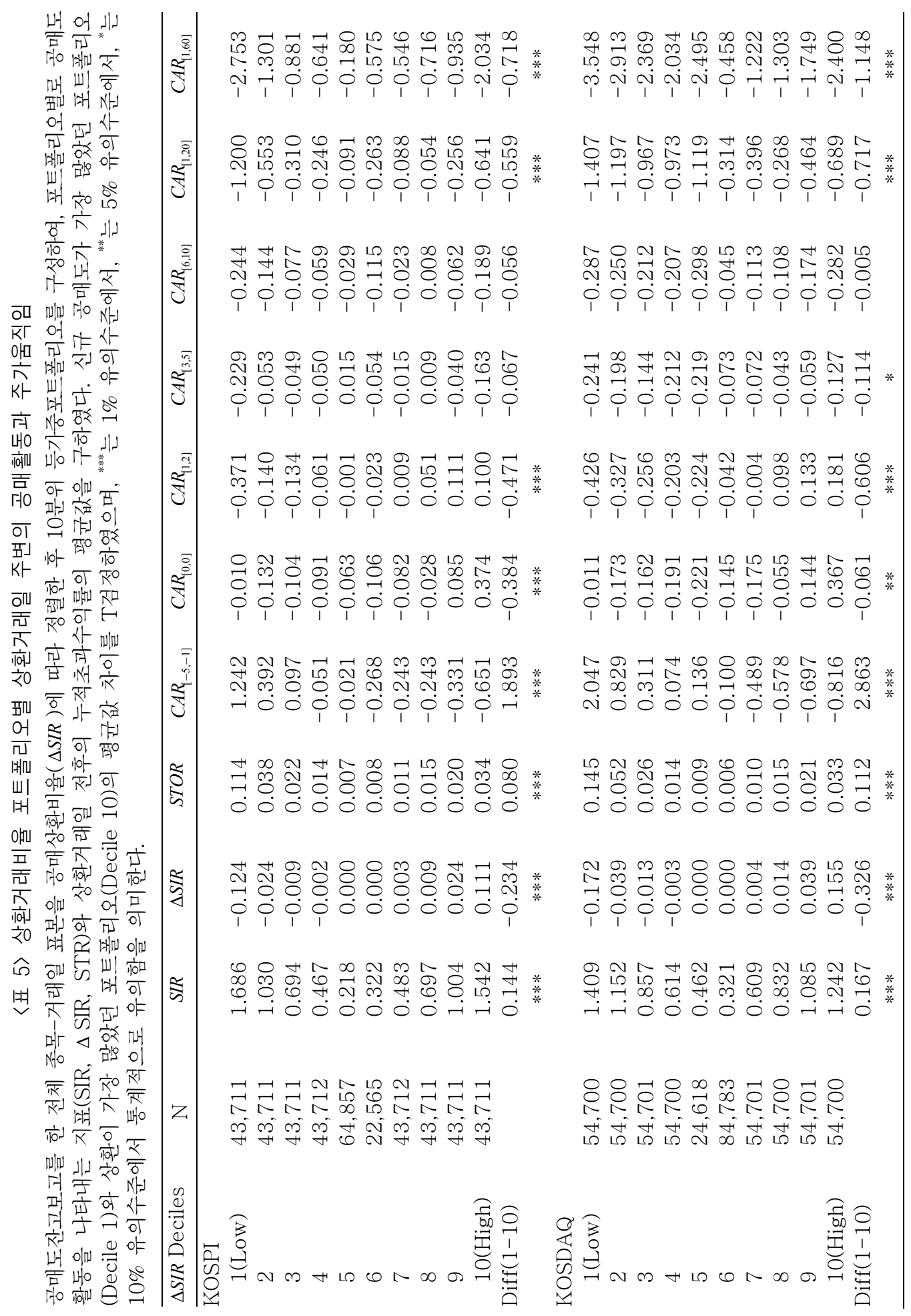


한국증권학회지 제 50 권 1호 (2021)

한편, 사건일 직전 수익률 $\left(C A R_{[-5,-1]}\right)$ 은 $\mathrm{D} 1$ 에서 $\mathrm{D} 10$ 으로 갈수록 대체로 감소해, $\mathrm{D} 1$ 에서는 $1.242 \%(2.047 \%), \mathrm{D} 10$ 에서는 $-0.651 \%(-0.816 \%)$ 를 기록했다. 공매거래자들이 직전 5 거래일 주가가 하락할수록 (포지션이익이 커질수록) 더 많은 포지션을 상환하고, 주가가 상승할 수록 (포지션손실이 커질수록) 포지션을 유지하거나 추가공매를 하는 것으로 보인다. 공매시와 상환시 모두에서 직전주가와 반대방향으로 거래하는 역추세 추종거래를 한 것이다. 사건일 수익률 $\left(C R_{[0,0]}\right)$ 은 $\mathrm{D} 10$ 으로 갈수록 증가해 $\mathrm{D} 2$ 에서는 $-0.132 \%(-0.173 \%), \mathrm{D} 10$ 에서는 $0.374 \%$ $(0.367 \%)$ 를 기록했으며, 사건일 직후 수익률 $\left(C A R_{[1,2]}\right)$ 에서도 비슷한 패턴이 나타났다. 추가공매에 따른 가격하락과 상환매수에 따른 가격상승이 발생했고, 상환매수 시 가격충격이 추가공매 시보다 컸음을 알 수 있었다. $C A R_{[3,5]}, C A R_{[6,10]}$ 에는 더 이상 패턴이 관찰되지 않아, 상환거래 또는 추가공매에 따른 가격충격이 일시적이었음을 알 수 있었다. 사건일 이후 1 3개월 평균초과 수익률 $\left(C A R_{[1,20]}, C A R_{[1,60]}\right)$ 은 모든 포트폴리오에서 음의 값을 보고했으며, D5 D6에서 절대 값이 가장 적고, 양 극단으로 갈수록 절대값이 커지는 것으로 나타났다. 추가공매가 많이 일어난 포트폴리오(D1)는 이후 20거래일 동안 $-1.200 \%(-1.407 \%), 60$ 거래일 동안 $-2.753 \%$ $(-3.548 \%)$ 주가가 하락한 것으로 나타나, 공매거래자가 주가하락을 올바르게 예측하고 추가공매를 한 것으로 보인다. 공매상환비율이 가장 큰 포트폴리오(D10)는 이후 20거래일 동안 $-0.641 \%(-0.689 \%), 60$ 거래일 동안 $-2.034 \%(-2.400 \%)$ 주가가 하락해, 투자자가 상환 시점을 잘못 선택해 기회손실을 입은 것으로 보인다. 공매거래자가 공매시에는 정보거래자의 속성을 보이지만, 상환거래 시에서는 외부환경 및 비합리적인 행태적 편의의 영향을 받는 것으로 추정된다.

\section{3 유형별 대량상환 거래일 주변의 주가움직임}

상환거래일 이후 1 3개월 동안 주가가 하락한 것으로 보아 공매거래자는 외부환경 및 행태적 편의로 공매포지션을 조기에 청산함으로써 기회손실을 부담한 것으로 보인다. 이 현상은 '솟스퀴즈(short squeeze)'와 관련된 일부 종목에 의해 유도되었을 가능성이 있다. 미 SEC는 솟스퀴즈를 갑작스러운 가격 상승 또는 증권대여의 어려움으로 인해 공매투자자 에게 주어지는 포지션 청산 압력으로 정의하며, 이 경우 공매거래자의 집중 상환매수로 해당주식의 주가가 추가 상승하게 되고, 연쇄적으로 숏스퀴즈가 발생할 수 있다고 하였다. ${ }^{15)}$ D'Avolio(2002)는 주식대여자의 갑작스러운 상환요청으로 공매투자자가 비자발적 환매를 할 경우 환매압박비용(cost of recall squeezes)이 발생하여 공매수익률이 떨어짐을 보이고,

15 ) SEC website(http://www.sec.gov/spotlight/keyregshoissyes.htm)의 원문은 아래와 같다. "The term 'short squeeze' refers to the pressure on short sellers to cover their positions as a result of sharp price increases or difficulty in borrowing the security the sellers short. The rush by short sellers to cover produces additional upward pressure on the price of the stock, which then can cause an even greater squeeze". 
Price Movements around Short Covering Trades

환매압박비용이 대주(대차)수수료, 업틱룰, 증거금 등과 함께 공매비용(cost of short sales)으로 고려되어야 한다고 주장하기도 했다.

이 연구에서는 전체 상환거래 내에 고평가가 해소됨에 따라 이루어진 정보거래 성격의 상환과 마진콜, 주식대여만기 도래 등 외부환경으로 인한 비자발적 상환 등 이질적인 거래가 혼재되어 있다고 보고, 상환거래 중 정보거래로 추정되는 것과 숏스퀴즈 거래로 추정되는 것을 골라 두 유형의 대량거래 이후 주가움직임을 비교 분석해 보았다. Boehmer et al.(2018)은 총 공매거래량과 직전수익률을 이용해 정보거래를 식별했으며, Liu and $\mathrm{Xu}(2016)$ 는 급격한 가격상승(일별 수익률 $15 \%$ 이상)과 높은 공매잔고비율(월별 공매잔고비율 상위 10\%)을 이용해 솟스퀴즈 종목을 선별했다. 이들 연구는 일단위 상환거래 데이터가 없었기 때문에, 실제 선별된 종목에서 상환거래가 발생했고 이것이 이후 주가움직임과 관련되었음을 보여 주지 못했다는 한계가 있었다. 우리는 선행연구와 같이 직전일 공매도잔고 $\left(\operatorname{SIR}_{t-1}\right)$, 직전 수익률 $\left(C A R_{[-5,-1]}\right)$ 을 선별기준으로 이용하되, 상환거래비율 $\left(\Delta \operatorname{SIR}_{t}\right)$ 을 추가하여 대규모 유형별 상환거래를 식별하였다. 즉, 직전일 공매도잔고와 공매상환비율이 상위 $10 \%$ 이면서 직전주 수익률 상위 $10 \%$ 인 종목을 골라 패자 포트폴리오(Loser)를, 공매도잔고와 공매상환비율은 동일하게 상위 $10 \%$ 이지만, 직전주 수익률이 하위 $10 \%$ 인 종목을 골라 승자 포트폴리오 (Winner)를 구성했다. 패자 포트폴리오는 직전 5거래일간 공매수익률이 나브지만, 공매잔고 부담이 커 비자발적으로 공매포지션을 대량 청산한 종목이므로 솟스퀴즈 거래로 볼 수 있고, 승자 포트폴리오는 직전 5 거래일간 공매수익률이 좋고 공매잔고가 많아 차익을 대량 실현한 종목이므로 정보거래로 볼 수 있다.

<표 6>에서 알 수 있듯이, $S I R_{t-1}$ 은 패자 포트폴리오가 승자 포트폴리오보다 높았고, $\Delta \operatorname{SIR}_{t}$ 은 승자 포트폴리오가 패자 포트폴리오보다 높았다. $C A R_{[-5,-1]}$ 는 승자 포트폴리오가 $-9.669 \%$ $(-11.883 \%)$, 패자 포트폴리오가 $10.912 \%(14.813 \%)$ 인 것으로 나타났다. 패자(승자) 포트 폴리오는 발행주식수의 약 3.5 4.0\%에 해당하는 공매포지션을 보유한 상태에서 직전 5 거래일 동안 $10 \%$ 이상 주가 급등(급락)으로 투자손실(투자이익)이 발생해 대규모 상환매수를 한 종목으로 구성된 셈이다. $C A R_{[0,0]}$ 은 패자 포트폴리오(유가증권시장 $0.843 \%$, 코스닥시장 $1.927 \%$ )가 승자 포트폴리오(유가증권시장 $0.221 \%$, 코스닥시장 $-0.018 \%$ )보다 높아, 솟스 퀴즈 시 가격충격이 차익실현 시에 비해 큰 것으로 나타났다. $C A R_{[1,20]}$ 은 패자 포트폴리오가 음수(유가증권 $-1,563 \%$, 코스닥 $-0.082 \%$ )인데 반해 승자 포트폴리오는 양수(유가증권 $0.370 \%$, 코스닥 $1.036 \%$ )인 것으로 나타나 솟스퀴즈로 인한 상환거래에서는 이후 주가가 추가하락 해 기회손실이 발생했지만, 차익실현을 위해 상환한 경우에는 오히려 주가가 상승해 손실을 피했음을 알 수 있었다. $C A R_{[1,60]}$ 두 포트폴리오 모두 음의 값을 보였지만, 패자의 수익률이 승자보다 낮았다. 요약하면, 솟스퀴즈가 추정되는 상황에서 발생한 대량상환이 차익실현 목적의 대량상환에 비해 큰 가격충격을 갖고 있고, 상환거래일 이후 1 3개월 동안 주가가 더 많이 하락했다. 


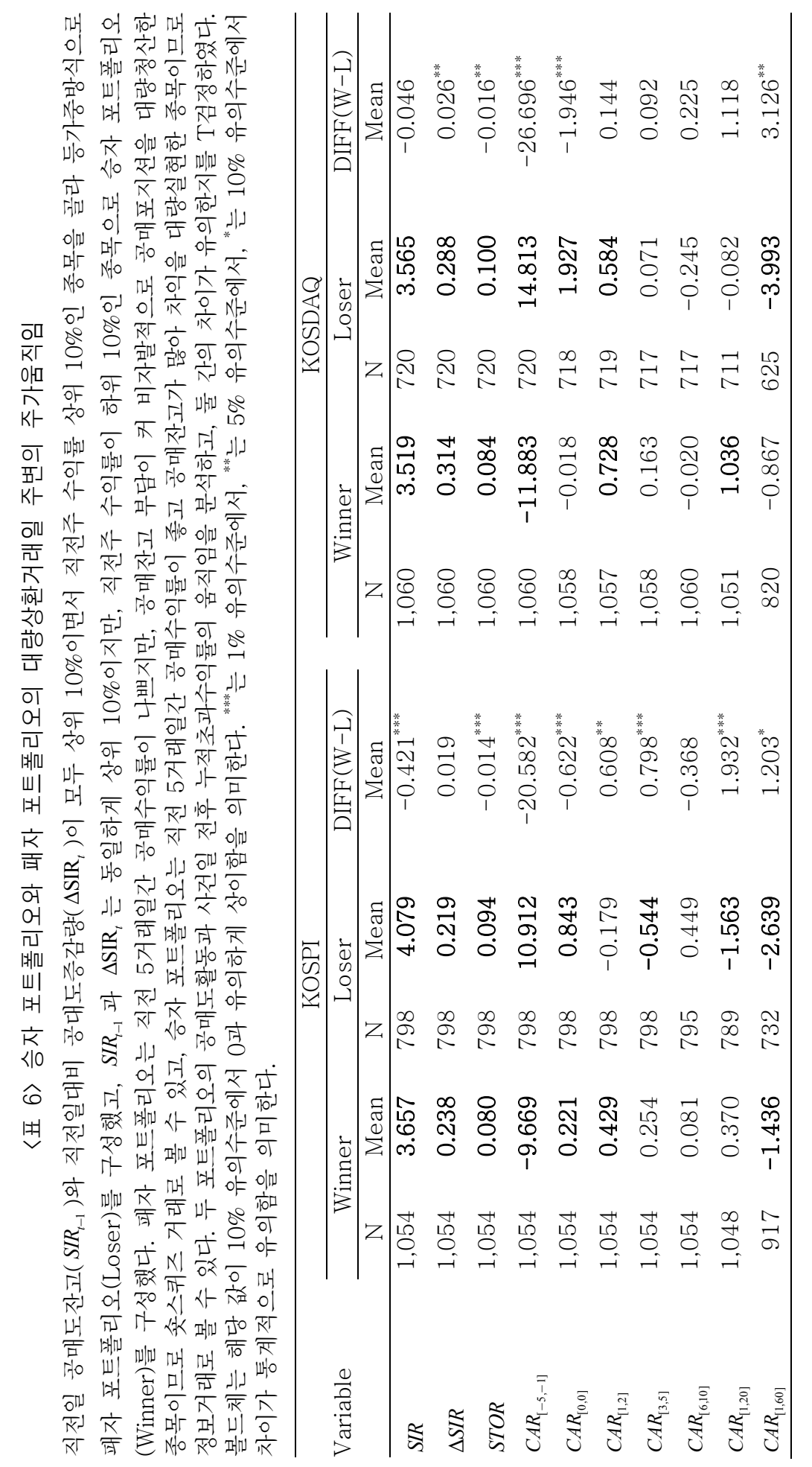


Price Movements around Short Covering Trades

\section{4 공매상환거래에 대한 주가반응에 관한 회귀분석}

공매상환거래 주변의 주가움직임이 주가에 영향을 미치는 다른 요인을 통제한 후에도 관찰되는지를 확인하기 위해 각 종목의 일별 초과수익률을 종속변수로 하고, 상환일 주변 일을 지정한 더미변수를 주요 설명변수로 한 회귀분석(식 (1))과 숏스퀴즈 성격의 상환거래와 정보거래 성격의 상관거래 주변일을 지정한 더미변수를 추가한 회귀분석(식 (2))을 아래와 같이 실시하였다. ${ }^{16)}$

$$
\begin{aligned}
A R_{t}= & \beta_{0}+\beta_{1} D_{[-5,-1]}+\beta_{2} D_{[0,0]}+\beta_{3} D_{[1,5]}+\beta_{4} D_{[6,10]}+\beta_{5} D_{[11,15]}+\beta_{6} D_{[16,20]}+\beta_{7} \text { Controls } \\
A R_{t}= & \beta_{0}+\beta_{1} D_{[-5,-1]}+\beta_{2} D_{[0,0]}+\beta_{3} D_{[1,5]}+\beta_{4} D_{[6,10]}+\beta_{5} D_{[11,15]}+\beta_{6} D_{[16,20]} \\
& +\beta_{7} D L_{[-5,-1]}+\beta_{8} D L_{[0,0]}+\beta_{9} D L_{[1,5]}+\beta_{10} D L_{[6,10]}+\beta_{11} D L_{[11,15]}+\beta_{12} D L_{[16,20]} \\
& +\beta_{13} D W_{[-5,-1]}+\beta_{14} D W_{[0,0]}+\beta_{15} D W_{[1,5]}+\beta_{16} D W_{[6,10]}+\beta_{17} D W_{[11,15]}+\beta_{18} D W_{[16,20]} \\
& +\beta_{19} \text { Controls }
\end{aligned}
$$

$A R \in\{V W A R, E W A R\}$

Controls $\in\left\{S_{I Z E_{t}}, B T M_{t}, T O_{t}, F O_{t}, A R_{t-1}, \Delta S I R_{t}, S_{R} R_{t-1}\right\}$

주가에 영향을 미치는 것으로 알려진 기업규모, 장부가치 대 시장가치비율, 회전율, 외국인 지분율, 직전거래일 수익률을 통제하였고, 공매거래활동이 주가에 미치는 영향을 살펴보기 위해 공매상환비율과 직전일 공매잔고비율을 설명변수로 포함시켰다. 종속변수로 가치가중 시장조정수익률과 등가중 시장조정수익률을 사용하였고, 두 경우의 결과는 유사하였다. 각 변수에 대한 설명은 제 3.3절에 있다. 단순 OLS분석과 횡단면과 시계열상의 이분산성을 통제 하기 위해 횡단면효과와 시계열효과를 통제한 패널회귀분석을 각각 실시하였으며, 결과는 <표 7> 패널 $\mathrm{A}$ 와 $\mathrm{B}$ 에 나타나 있다.

식 (1)에서 주요변수는 상환거래일 주변일을 지정하는 5 개의 더미변수 $\left(D_{[-5,-1]} \sim D_{[16,20]}\right)$ 이다. $D_{[-5,-1]}$ 은 상환거래일 직전 5 거래일에 1 의 값을 갖고, 그 외에는 0 의 값을 갖는 더미변수이며, $D_{[0,0]}, D_{[1,5]}, D_{[6,10]}, D_{[1,15]}, D_{[16,20]}$ 도 동일한 방식으로 정의하였다. 만약 상환거래 직전에 주가가 하락하였다면 $\beta_{1}$ 이 음의 값을 보일 것이고, 상환 당일 가격충격이 있었다면 $\beta_{2}$ 가 양의 값을 나타낼 것이다. 상환거래 후 20 거래일 동안 누적초과수익률은 $\beta_{3} \sim \beta_{6}$ 를 합산한 값의 5 배가 된다.

솟스퀴즈로 인한 상환거래가 발생했을 때 주가움직임을 살펴보기 위해 직전일 공매잔고 비율, 공매상환비율, 직전 5 거래일 수익률이 상위 $10 \%$ 인 종목-거래일 표본을 선별한 후, 이 거래일 주변의 날짜를 더미변수로 지정하였다. $D L_{[-5,-1]}, D L_{[0,0]}, D L_{[1,5]}, D L_{[6,10]}, D L_{[11,15]}, D L_{[16,20]}$ 직전일 공매잔고비율과 공매상환비율이 상위 $10 \%$ 이면서 직전 5 거래일 수익률이 하위 $10 \%$ 인 종목-거래일 표본을 정보거래 성격의 상환거래로 정의하고, 이것이 발생한 주변일에 대해서도

16) 회귀분석모델은 Diether et al.(2009b)와 Boehmer et al.(2018)과 유사하다. 
한국증권학회지 제 50 권 1호 (2021)

〈표 7〉공매도상환에 대한 시장반응에 관한 회귀분석

각 종목의 일별시장조정수익률을 종속변수로 하고, 상환일 주변일을 지정한 더미변수를 주요설명변수로 한 회귀 분석결과이다. $D_{[-5,-1]}$ 은 상환거래일 직전 5 거래일에 1 의 값을 갖고, 그 외에는 0 의 값을 갖는 더미변수이고, $D_{[0,0]}$ 은 공매상환일 당일 1 의 값을 갖고, 그 외에는 0 의 값을 갖는 더미변수이다. $D_{[1,5]}$, $D_{[6,10]}, D_{[11,15]}, D_{[16,20]}$ 도 동일한 방식으로 정의하였다. $D L$ 은 직전일 공매잔고비율, 공매상환비율, 직전 5 거래일 수익률이 상위 $10 \%$ 인 종목-거래일 표본에 대해 동일한 방식으로 지정한 더미변수이고, $D W$ 는 직전일 공매잔고비율, 공매상환비율이 상위 $10 \%$ 이고, 직전 5 거래일 수익률이 하위 $10 \%$ 인 종목거래일 표본에 대해 동일한 방식으로 지정한 더미변수이다. $\triangle S I R$ 은 해당종목의 상환량을, $S I R_{t-1}$ 은 직전거래일의 공매잔고를 나타낸다. 주가에 영향을 미치는 것으로 알려진 기업규모( SIZE ), 장부가치 대 시장가치비율( $B T M)$, 회전율( $T O)$, 외국인지분률( $F O R)$, 직전거래일 수익률( $\left.A R_{t-1}\right)$ 을 통제하였고, 공매거래활동이 주가에 미치는 영향을 살펴보기 위해 공매상환비율 $\left(\Delta \mathrm{SIR}_{t}\right)$ 과 직전일 공매잔고비율 $\left(S_{t-1}\right)$ 도 설명변수로 포함시켰다. 패널 $\mathrm{A}$ 는 simple OLS 결과이고, 패널 $\mathrm{B}$ 는 횡단면효과와 시계열효과를 통제한 패널회귀분석 결과이다. ***는 $1 \%$ 유의수준에서, ${ }^{* *}$ 는 $5 \%$ 유의수준에서, ${ }^{*}$ 는 $10 \%$ 유의수준에서 통계적으로 유의함을 의미한다.

패널 A: Simple OLS

\begin{tabular}{|c|c|c|c|c|c|c|c|c|}
\hline \multirow[b]{3}{*}{ Intercept } & \multicolumn{4}{|c|}{ KOSPI } & \multicolumn{4}{|c|}{ KOSDAQ } \\
\hline & \multicolumn{2}{|c|}{ VWAR } & \multicolumn{2}{|c|}{ EWAR } & \multicolumn{2}{|c|}{ VWAR } & \multicolumn{2}{|c|}{ EWAR } \\
\hline & $-1.54^{* * *}$ & $-1.47^{* * * *}$ & $-1.36^{* * * *}$ & $-1.30^{* * *}$ & $-3.38^{* * * *}$ & $-3.31^{* * * *}$ & $-2.87^{* * * *}$ & $-2.81^{* * * *}$ \\
\hline$D_{[-5,-1]}$ & $-0.12^{* * *}$ & $-0.11^{* * *}$ & $-0.09^{* * *}$ & $-0.08^{* * *}$ & $-0.16^{* * *}$ & $-0.16^{* * * *}$ & $-0.09^{* * *}$ & $-0.09^{* * *}$ \\
\hline$D_{[0,0]}$ & $0.24^{* * * *}$ & $0.24^{* * *}$ & $0.14^{* * *}$ & $0.14^{* * * *}$ & $0.32^{* * * *}$ & $0.32^{* * * *}$ & $0.16^{* * *}$ & $0.16^{* * *}$ \\
\hline$D_{[1,5]}$ & $-0.05^{* * *}$ & $-0.05^{* * *}$ & $-0.04^{* * * *}$ & $-0.04^{* * *}$ & $-0.03^{* * * *}$ & $-0.03^{* * * *}$ & $-0.04^{* * * *}$ & $-0.04^{* * * *}$ \\
\hline$D_{[6,10]}$ & $-0.03^{* * *}$ & $-0.03^{* *}$ & $-0.04^{* * *}$ & $-0.03^{* * *}$ & $-0.05^{* * *}$ & $-0.06^{* * *}$ & $-0.06^{* * *}$ & $-0.06^{* * *}$ \\
\hline$D_{[11,15]}$ & $-0.04^{* * *}$ & $-0.04^{* * * *}$ & $-0.03^{* * * *}$ & $-0.03^{* * *}$ & $-0.06^{* * *}$ & $-0.05^{* * * *}$ & $-0.04^{* * * *}$ & $-0.04^{* * * *}$ \\
\hline$D_{[16,20]}$ & $-0.06^{* * *}$ & $-0.06^{* * *}$ & $-0.03^{* * *}$ & $-0.03^{* * *}$ & $-0.07^{* * *}$ & $-0.07^{* * *}$ & $-0.04^{* * * *}$ & $-0.04^{* * *}$ \\
\hline$D L_{[-5,-1]}$ & & $2.11^{* * *}$ & & $1.95^{* * * *}$ & & $2.78^{* * * *}$ & & $2.57^{* * * *}$ \\
\hline$D L_{[0,0]}$ & & $0.19^{* *}$ & & $0.25^{* * * *}$ & & $1.10^{* * *}$ & & $1.28^{* * *}$ \\
\hline$D L_{[1,5]}$ & & $-0.34^{* * * *}$ & & $-0.36^{* * *}$ & & $-0.24^{* * *}$ & & $-0.31^{* * *}$ \\
\hline$D L_{[6,10]}$ & & $0.09^{*}$ & & 0.06 & & -0.01 & & $-0.15^{* *}$ \\
\hline$D L_{[11,15]}$ & & $-0.14^{* * *}$ & & $-0.12^{* * *}$ & & -0.01 & & -0.05 \\
\hline$D L_{[16,20]}$ & & $-0.08^{*}$ & & $-0.08^{*}$ & & -0.05 & & $-0.10^{*}$ \\
\hline$D W_{[-5,-1]}$ & & $-2.27^{* * *}$ & & $-1.89^{* * *}$ & & $-2.83^{* * *}$ & & $-2.27^{* * * *}$ \\
\hline$D W_{[0,0]}$ & & $0.41^{* * *}$ & & $0.52^{* * *}$ & & $0.24^{* *}$ & & $0.36^{* * * *}$ \\
\hline$D W_{[1,5]}$ & & $0.25^{* * *}$ & & $0.20^{* * * *}$ & & $0.49^{* * * *}$ & & $0.33^{* * * *}$ \\
\hline$D W_{[6,10]}$ & & 0.06 & & $0.08^{*}$ & & $0.15^{* * * *}$ & & $0.10^{*}$ \\
\hline$D W_{[11,15]}$ & & 0.05 & & $0.08^{*}$ & & 0.05 & & 0.08 \\
\hline$D W_{[16,20]}$ & & $0.18^{* * * *}$ & & $0.10^{* *}$ & & $0.28^{* * *}$ & & $0.16^{* * *}$ \\
\hline$\Delta S I R$ & $0.62^{* * * *}$ & $0.50^{* * * *}$ & $0.56^{* * * *}$ & $0.44^{* * * *}$ & $-0.08^{*}$ & $-0.16^{* * * *}$ & 0.01 & $-0.08^{*}$ \\
\hline$S I R_{t-1}$ & $-0.03^{* * *}$ & $-0.02^{* * *}$ & $-0.02^{* * *}$ & $-0.02^{* * *}$ & $-0.07^{* * *}$ & $-0.07^{* * * *}$ & $-0.06^{* * *}$ & $-0.06^{* * *}$ \\
\hline SIZE & $0.06^{* * *}$ & $0.06^{* * * *}$ & $0.05^{* * * *}$ & $0.05^{* * * *}$ & $0.14^{* * * *}$ & $0.13^{* * *}$ & $0.12^{* * *}$ & $0.12^{* * *}$ \\
\hline$B T M$ & 0.00 & 0.00 & 0.00 & 0.00 & $0.01^{* * * *}$ & $0.01^{* * * *}$ & $0.01^{* * *}$ & $0.00^{* * * *}$ \\
\hline то & $0.04^{* * *}$ & $0.04^{* * *}$ & $0.04^{* * * *}$ & $0.04^{* * *}$ & $0.02^{* * * *}$ & $0.02^{* * * *}$ & $0.02^{* * * *}$ & $0.02^{* * * *}$ \\
\hline$F O$ & $0.00^{* * *}$ & $0.00^{* * *}$ & $0.00^{* * * *}$ & $0.00^{* * * *}$ & $0.00^{* * * *}$ & $0.00^{* * * *}$ & $0.00^{* * * *}$ & $0.00^{* * *}$ \\
\hline$A R_{t-1}$ & $0.00^{* *}$ & $-0.01^{* * * *}$ & $-0.02^{* * * *}$ & $-0.02^{* * *}$ & $0.01^{* * *}$ & $0.01^{* * * *}$ & $0.00^{* * * *}$ & $-0.01^{* * * *}$ \\
\hline Adj. $R^{2}$ & 0.013 & 0.020 & 0.014 & 0.020 & 0.009 & 0.013 & 0.008 & 0.012 \\
\hline
\end{tabular}


Price Movements around Short Covering Trades

〈표 7〉 공매도상환에 대한 시장반응에 관한 회귀분석(계속)

패널 $\mathrm{B}$ : 패널회귀분석

\begin{tabular}{|c|c|c|c|c|c|c|c|c|}
\hline \multirow[b]{3}{*}{ Intercept } & \multicolumn{4}{|c|}{ KOSPI } & \multicolumn{4}{|c|}{ KOSDAQ } \\
\hline & \multicolumn{2}{|c|}{ VWAR } & \multicolumn{2}{|c|}{ EWAR } & \multicolumn{2}{|c|}{ VWAR } & \multicolumn{2}{|c|}{ EWAR } \\
\hline & $-3.38^{* * *}$ & $-3.05^{* * *}$ & $-3.29^{* * * *}$ & $-2.66^{* * *}$ & $-6.71^{* * *}$ & $-6.32^{* * * *}$ & $-6.69^{* * * *}$ & $-6.30^{* * *}$ \\
\hline$D_{[-5,-1]}$ & $-0.17^{* * *}$ & $-0.17^{* * *}$ & $-0.17^{* * *}$ & $-0.09^{* * *}$ & $-0.32^{* * *}$ & $-0.32^{* * *}$ & $-0.32^{* * *}$ & $-0.32^{* * *}$ \\
\hline$D_{[0,0]}$ & $0.14^{* * *}$ & $0.14^{* * *}$ & $0.15^{* * * *}$ & $0.13^{* * *}$ & $0.16^{* * *}$ & $0.16^{* * * *}$ & $0.17^{* * * *}$ & $0.17^{* * *}$ \\
\hline$D_{[1,5]}$ & -0.00 & -0.00 & -0.00 & $-0.04^{* * *}$ & $0.04^{* * *}$ & $0.04^{* * * *}$ & $0.03^{* * *}$ & $0.03^{* * *}$ \\
\hline$D_{[6,10]}$ & $-0.04^{* * *}$ & $-0.03^{* * *}$ & $-0.03^{* * *}$ & $-0.04^{* * *}$ & $-0.04^{* * *}$ & $-0.04^{* * *}$ & $-0.04^{* * *}$ & $-0.04^{* * *}$ \\
\hline$D_{[11,15]}$ & $-0.03^{* * *}$ & $-0.03^{* * *}$ & $-0.03^{* *}$ & $-0.03^{* * *}$ & $-0.03^{* * *}$ & $-0.03^{* *}$ & $-0.03^{* *}$ & $-0.03^{* *}$ \\
\hline$D_{[16,20]}$ & $-0.04^{* * *}$ & $-0.04^{* * *}$ & $-0.03^{* * *}$ & $-0.03^{* * *}$ & $-0.02^{*}$ & $-0.02^{*}$ & -0.01 & -0.01 \\
\hline$D L_{[-5,-1]}$ & & $1.93^{* * *}$ & & $1.94^{* * *}$ & & $2.37^{* * * *}$ & & $2.38^{* * * *}$ \\
\hline$D L_{[0,0]}$ & & $0.19^{* *}$ & & $0.23^{* *}$ & & $0.80^{* * * *}$ & & $0.80^{* * *}$ \\
\hline$D L_{[1,5]}$ & & $-0.37^{* * *}$ & & $-0.36^{* * * *}$ & & $-0.53^{* * *}$ & & $-0.52^{* * *}$ \\
\hline$D L_{[6,10]}$ & & 0.03 & & 0.04 & & $-0.25^{* * *}$ & & $-0.25^{* * *}$ \\
\hline$D L_{[11,15]}$ & & $-0.13^{* * *}$ & & $-0.13^{* * *}$ & & $-0.11^{*}$ & & $-0.11^{*}$ \\
\hline$D L_{[16,20]}$ & & $-0.09^{* *}$ & & $-0.09^{* *}$ & & $-0.17^{* * *}$ & & $-0.18^{* * *}$ \\
\hline$D W_{[-5,-1]}$ & & $-1.88^{* * *}$ & & $-1.90^{* * *}$ & & $-2.27^{* * * *}$ & & $-2.27^{* * *}$ \\
\hline$D W_{[0,0]}$ & & $0.43^{* * *}$ & & $0.50^{* * *}$ & & -0.09 & & -0.06 \\
\hline$D W_{[1,5]}$ & & $0.17^{* * *}$ & & $0.18^{* * *}$ & & $0.25^{* * * *}$ & & $0.26^{* * *}$ \\
\hline$D W_{[6,10]}$ & & 0.05 & & $0.06^{*}$ & & $0.06^{*}$ & & $0.07^{*}$ \\
\hline$D W_{[11,15]}$ & & $0.06^{*}$ & & 0.06 & & 0.05 & & 0.06 \\
\hline$D W_{[16,20]}$ & & $0.07^{*}$ & & $0.07^{*}$ & & $0.14^{* *}$ & & $0.15^{* * *}$ \\
\hline$\Delta S I R$ & $0.71^{* * *}$ & $0.60 * * *$ & $0.72^{* * * *}$ & $0.48^{* * *}$ & $0.50^{* * *}$ & $0.44^{* * * *}$ & $0.50^{* * * *}$ & $0.44^{* * *}$ \\
\hline$S I R_{t-1}$ & $-0.04^{* * *}$ & $-0.04^{* * *}$ & $-0.04^{* * *}$ & $-0.04^{* * *}$ & $-0.13^{* * *}$ & $-0.12^{* * *}$ & $-0.13^{* * *}$ & $-0.12^{* * *}$ \\
\hline SIZE & $0.13^{* * *}$ & $0.11^{* * *}$ & $0.13^{* * *}$ & $0.10^{* * *}$ & $0.26^{* * *}$ & $0.25^{* * * *}$ & $0.26^{* * *}$ & $0.25^{* * *}$ \\
\hline BTM & $0.00^{* *}$ & $0.00^{* *}$ & $0.00^{* *}$ & $0.00^{* *}$ & $0.00^{* *}$ & $0.00^{*}$ & $0.00^{* * *}$ & $0.00^{*}$ \\
\hline TO & $0.05^{* * *}$ & $0.05^{* * *}$ & $0.05^{* * *}$ & $0.04^{* * * *}$ & $0.09^{* * *}$ & $0.09^{* * * *}$ & $0.09^{* * *}$ & $0.09^{* * *}$ \\
\hline FO & $-0.00^{* * *}$ & $0.00^{* * *}$ & $-0.00^{* * *}$ & $0.0^{* * * *}$ & $-0.00^{* * *}$ & $0.00^{* * * *}$ & $-0.00^{* * * *}$ & $0.0^{* * *}$ \\
\hline$A R_{t-1}$ & $-0.01^{* * *}$ & $-0.02^{* * *}$ & $-0.01^{* * *}$ & $-0.02^{* * *}$ & $-0.02^{* * *}$ & $-0.02^{* * *}$ & $-0.02^{* * *}$ & $-0.02^{* * *}$ \\
\hline $\operatorname{Adj} . R^{2}$ & 0.019 & 0.028 & 0.019 & 0.022 & 0.047 & 0.054 & 0.047 & 0.053 \\
\hline
\end{tabular}

같은 방식으로 더미변수 $\left(D W_{[-5,-1]}, D W_{[0,0]}, D W_{[1,5]}, D W_{[6,10]}, D W_{[1,15]}, D W_{[16,20]}\right)$ 를 설정했다. 식 (2)의 $\beta_{7} \sim \beta_{12}$ 및 $\beta_{13} \sim \beta_{18}$ 은 각각 솟스퀴즈로 인한 상환매수와 정보거래 목적의 상환매수시 주가 움직임이 일반적인 숏커버링과 어떻게 다른지를 나타낸다. 직전 주가가 급등한 거래를 솟스 퀴즈로, 급락한 거래를 정보거래로 정의하였기 때문에 $\beta_{7}$ 은 양수로, $\beta_{13}$ 은 음수로 나타날 것이다. 또 솟스퀴즈 거래가 가격충격과 기회손실이 크다면, $\beta_{8}$ 은 양의 값을 보일 것이고, $\beta_{9} \sim \beta_{12}$ 를 합산한 값은 음의 부호를 보일 것이다.

분석결과(<표 $7>$ 칼럼 $1,3,5,7), D_{[-5,-1]}$ 은 음의 계수를, $D_{[0,0]}$ 은 양의 계수를 갖는 것으로 나타나, 공매거래자가 상환시에도 컨트래리안 거래를 함을 알 수 있었고, 상환거래시 주가가 일시적으로 상승하는 가격충격이 있음을 알 수 있었다. 특히 주가에 영향을 미치는 다른 
한국증권학회지 제 50 권 1호 (2021)

요인을 통제하니, 단변량분석(<표 $4>$ )에서 보다 더 큰 가격충격이 관찰되었다. $D_{[1,5]}, D_{[6,10]}$, $D_{[11,15]}, D_{[16,20]}, D_{[6,10]}, D_{[1,15]}, D_{[16,20]}$ 는 모두 유의한 음의 계수를 보여, 포지션을 청산한 종목의 주가가 상환일 이후 추가로 하락함을 알 수 있었다.

칼럼 $2,4,6,8$ 은 숏스퀴즈와 정보거래로 추정되는 상환거래 주변의 주가움직임을 분석한 회귀분석(식 (2))의 결과이다. $D L_{[-5,-1]}$ 은 양 시장 모두에서 큰 양의 계수를, $D W_{[-5,-1]}$ 은 큰 음의 계수를 보이고 있는데, 이는 직전일 공매잔고비율, 공매상환비율이 상위 $10 \%$ 인 종목 중 큰 공매손실이 예상되는 표본을 ‘솟스퀴즈'로, 큰 공매이익이 예상되는 표본을 ‘정보거래'로 본 이 연구의 정의와 일치하는 결과이다. $D L_{[0,0]}$ 은 큰 양의 계수를 보여, 상환거래가 발생한 전체 표본의 가격충격(유가증권시장 $0.14 \%$, 코스닥시장 $0.16 \%$ )에 비해 숏스퀴즈가 발생한 표본의 가격충격(유가증권시장 $0.39 \%$, 코스닥시장 $1.44 \%$ )이 훨씬 크다는 것을 알 수 있다. $D W_{[0,0]}$ 도 통계적으로 유의한 양의 계수를 보고해 정보거래 성격의 상환매수 역시 일반적인 숏커버링보다 큰 가격충격을 갖고 있음을 알 수 있었다. 코스닥시장의 경우 $D W_{[0,0]}$ 의 계수가 $D L_{[0,0]}$ 보다 작아, 솟스퀴즈 상환거래의 가격충격이 정보거래 목적의 상환매수에 비해 큰 것으로 나타났다. $D L_{[1,5]}, D L_{[6,10]}, D L_{[11,15]}, D L_{[16,20]}$ 는 대체로 큰 음의 계수를 보이고 있어, 솟스 퀴즈가 발생한 표본에서 포지션 청산 후 20거래일 동안 주가가 하락했으며 그 하락폭은 일반적인 상환거래에 비해 컸음을 알 수 있었다. 상환거래가 발생한 표본은 이후 20거래일 동안 평균 $-0.65 \%(-0.90 \%)$ 하락한 반면, 솟스퀴즈로 추정되는 표본은 평균 $-3.15 \%(-3.95 \%)$ 하락했다. $D W_{[1,5]}, D W_{[6,10]}, D W_{[11,15]}, D W_{[16,20]}$ 는 유의한 양의 계수를 보여, 정보거래 성격의 상환 거래 발생시 포지션 청산 후 20거래일 동안 주가가 평균 $1.65 \%(3.45 \%)$ 상승하였음을 알 수 있었다. 거래자들이 고평가가 해소되거나 새로운 정보유입으로 해당 주식이 저평가 상태로 바뀐 시점을 포착하여 주가상승 직전에 공매포지션을 청산하는 것으로 볼 수 있다. 한편, $\Delta \mathrm{SIR}_{t}$ 는 유의한 양의 계수를 보여 상환거래 규모가 클수록 당일 주가가 크게 상승함을 알 수 있었고, $S I R_{t-1}$ 은 음의 계수를 보여 공매잔고비율이 많을수록 익일 수익률이 대체로 하락함을 알 수 있었다.

\section{5 강건성 분석}

먼저, 소형주와 유동성이 떨어지는 종목의 경우 기관투자자가 해당 주식을 적게 보유하기 때문에 대주(대차) 공급이 원활하지 않아 공매도거래가 정상적으로 이루어지지 않는다는 사실을 밝힌 선행연구 ${ }^{17)}$ 에 따라, 월말 주가가 하위 $10 \%$ 이면서 시가총액이 하위 $10 \%$ 인

17) D’Avolio(2002)는 미국주식시장에서 주가가 \$5 이하인 저가주의 3분의 1 은 공매가 불가능한데, 그 이유는 이들 주식을 대형수탁은행(large custody bank)으로부터 대주하는 것이 어렵기 때문이라고 설명하였다. 기관투자자가 장기보유주식을 대주수수료를 받고 대형수탁은행을 통해 대주하게 되는데 일반적으로 기관투자자는 규모가 크고 유동성이 좋은 주식을 선호하기 때문에, 소형주와 저유동성 주식은 대주(대차)가능주식의 공급이 원활하지 않다는 것이다. 
Price Movements around Short Covering Trades

종목을 공매거래가 정상적으로 이루어지지 않는 종목으로 보고 이것을 제외하여 표본을 구성한 후, 강건성을 검증하였다. 다음으로 이 연구의 결과가 $\mathrm{ETF}, \mathrm{ELW}$, 주식선물, 주식 옵션 거래에 수반한 헤지 목적의 공매, 주식 저유동성 종목에 대한 유동성공급자(LP)의 시장조성행위를 위한 공매 등에 의해 유도되었을 가능성을 차단하기 위해 공매잔고비율이 상위 $50 \%$ 이상인 종목만으로 데이터셋을 구성해 동일한 분석을 진행하였다. 헤지 및 차익 목적의 거래는 대규모 잔고를 축적하지 않을 것이기 때문에 이 같은 방법을 활용했다. 또 공매잔고 데이터셋에서 존재하는 불연속적인 거래일에서 공매상환비율 $(\Delta \mathrm{SIR})$ 이 과잉추정될 가능성이 있기 때문에, 불연속적인 거래일을 제외한 데이터셋을 구축하여 강건성 검증을 실시하였다. 모든 강건성 검증에서 유사한 결과가 확인되었다.

\section{5. 결론}

이 연구에서는 공매도보고제도에 의해 보고된 공매도잔고 자료를 활용하여 일별, 종목별 공매도상환거래 데이터셋을 구축하고 상환거래일 주변의 주가움직임을 분석함으로써 상환 거래가 직전수익률과 어떠한 관계를 갖고 있는지, 상환거래가 직후 수익률과 장기 수익률에 어떠한 영향을 미치는지를 살펴보았다. 분석결과, 직전 5 거래일 수익률이 낮을수록 공매 상환거래가 활발히 일어나, 공매도거래자들이 상환시에 (공매도시와 마찬가지로) 컨트래리안 거래를 한다는 것을 알 수 있었다. 공매도상환 당일과 직후거래일에 유의미한 가격상승이 나타나, 공매포지션 청산에 따른 수요충격이 존재함을 확인했다. 상환거래일 이후 장기 수익률이 음의 값을 보여, 공매도거래자가 적절한 시기에 상환을 못해 기회손실을 보고 있음을 알 수 있었다. 공매도거래자가 공매시에는 사적정보 및 투자스킬을 활용해 과대평가된 주식을 선별해 공매포지션을 형성하지만, 상환시에는 외부환경이나 비합리적인 투자행태 등으로 인해 포지션을 적기 청산하지 못해 기회손실을 부담한 것으로 보인다. 한편, 공매도 제약과 자본제약으로 인해 비자발적으로 발생한 대규모 상환거래(숏스퀴즈)에서 더 큰 가격 충격이 나타나고, 투자자들이 더 큰 기회손실을 부담한다는 것을 확인할 수 있었다.

최근 '게임스톱' 주가가 솟스퀴즈로 인해 급등락하면서 공매도 상환거래에 대한 관심이 높아졌다. 이 연구는 한국시장에서 공매상환거래일 주변의 주가움직임을 이용해 실증분석한 최초의 연구로, 공매상환거래가 솟스퀴즈 성격의 상환거래와 정보거래 성격의 상환거래 등 이질적인 거래로 구성되어 있고, 각각이 시장에 미치는 영향이 상이함을 보여주었다. 특히 주가급등으로 공매포지션의 손실이 커질 때 비자발적인 조기상환이 나타나며, 이 경우 매우 큰 가격충격이 나타나고, 공매거래자가 상당한 기회손실을 부담하여야 함을 알 수 있었다. 이상의 결과는 실무적으로 공매투자전략을 수립할 때 솟스퀴즈 가능성을 고려하여 관련 비용을 고려하여야 한다는 시사점을 주며, 공매와 관련된 정책을 수립할 때 상환거래도 함께 고려하여 시장안정기능을 검토하여야 한다는 시사점을 준다. 
한국증권학회지 제50권 1호 (2021)

\section{References}

Asquith, P., and L. Meulbroek, 1996, An Empirical Investigation of Short Interest, Working paper, Harvard University, Available at http://www.nber.org/papers/w10434

Asquith, P., P. Pathak, and J. Ritter, 2005, Short Interest, Institutional Ownership, and Stock Returns, Journal of Financial Economics, Vol. 78, pp. 243-276.

Beber, A., and M. Pagano, 2013, Short-selling Bans around the World: Evidence from the 2007-09 Crisis, Journal of Finance, Vol. 68, pp. 343-381.

Blau, B., B. V. Ness, and R. V. Ness, 2012, Trade Size and Price Clustering: The Case of Short Sales and the Suspension of Price Tests, The Journal of Financial Research, Vol. 35, pp. 159-182.

Boehmer, E., C. Jones, and X. Zhang, 2008, Which Shorts Are Informed? Journal of Finance, Vol. 63, pp. 491-527.

Boehmer, E., and J. Wu, 2012, Short Selling and the Price Discovery Process, Review of Financial Studies, Vol. 26, pp.287-322.

Boehmer, E., C. Jones, and X. Zhang, 2013, Shackling Short Sellers: The 2008 Shorting Ban, The Review of Financial Studies, Vol. 26, pp. 1363-1400.

Boehmer, E., T. Duong, and Z. Huszar, 2018, Short Covering Trades, Journal of Financial and Quantitative Analysis, Vol. 53, pp. 723-748.

Boulton, T., and M. Braga-Alves, 2010, The Skinny on the 2008 Naked Short-sale Restrictions, Journal of Financial Market, Vol. 13, pp. 397-421.

Choe, H., and H. Lee, 2012, Short Sales Restriction versus Short Sales Prohibition: Different Effects on Market Efficiency, Asian Review of Financial Research, Vol. 25, pp. 161-202.

Christophe, S., M. Ferri, and J. Angel, 2004, Short-selling prior to Earnings Announcements, Journal of Finance, Vol. 59, pp. 1845-1875.

Christophe, S., M. Ferri, and J. Hsieh, 2010, Informed Trading before Analyst Downgrades: Evidence from Short Sellers, Journal of Financial Economics, Vol. 95, pp. 86-106.

Dask, H., S. Richardson, and I. Tuna, 2005, Do Short Sale Transactions Precede Bad News Events? Working Paper, University of Pennsylvania, Available at http://dx.doi.org/10. 2139/ssrn.722242.

D’Avolio, G., 2002, The Market for Borrowing Stock, Journal of Financial Economics, Vol. 66, pp. 271-306.

Dechow, P., H. Amy, M. Lisa, and S. Richard, 2001, Short-sellers, Fundamental Analysis, and Stock Returns, Journal of Financial Economics, Vol. 61, pp. 77-106. 
Price Movements around Short Covering Trades

Desai, H., K. Ramesh, S. Thiagarajan, and B, Balachandran, 2002, An Investigation of the Informational Role of Short Interest in the Nasdaq Market, Journal of Finance, Vol. 10, pp. 2263-2287.

Diamond, D., and R. Verrecchia, 1987, Constraint on Short-selling and Asset Price Adjustment to Private Information, Journal of Financial Economics, Vol. 18, pp. 277-311.

Diether, K., K. Lee, and I. Werner, 2009a, It's SHO Time! Short-sale Price Tests and Market Quality, Journal of Finance, Vol. 64, pp. 37-73.

Diether, K., K. Lee, and I. Werner, 2009b, Short-sale Strategies and Return Predictability, The Review of Financial Studies, Vol. 22, pp. 575-607.

Engelberg, J., A. Reed, and M. Ringenberg, 2012, How Are Shorts Informed? Short Sellers, News, and Information Processing, Journal of Financial Economics, Vol. 105, pp. 260278.

Eom, Y., 2012, Short-selling Before Analyst Downgrades, Korean Journal of Financial Studies, Vol. 42, pp. 309-340.

Grinblatt, M., and B. Han, 2005, Prospect Theory, Mental Accounting, and the Disposition Effect, Journal of Financial Economics, Vol. 78, pp. 3331-3339.

Grinblatt, M., and M. Keloharju, 2001, What Makes Investors Trade? Journal of Finance, Vol. 56, pp. 589-616.

Hasbrouck, J., 1991, Measuring the Information Content of Stock Trades, Journal of Finance, Vol. 46, pp. 179-207.

Jank, S., C. Roling, and E. Smajlbegovic, 2021, Flying under the Radar: The Effects of Short-sale Disclosure Rules on Investor Behavior and Stock Prices, Journal of Financial Economics, Vol. 139, pp. 209-233.

Jarrow, R., 1992, Market Manipulations, Bubbles, Corners, and Short Squeezes, Journal of Financial and Quantitative Analysis, Vol. 27, pp. 311-336.

Jones, C., A. Reed, and W. Waller, 2016, Revealing Shorts: An Examination of Large Short Position Disclosures, The Review of Financial Studies, Vol. 29, pp. 3278-3320.

Woo, M., and M., Kim, 2019, Performance of Short-selling Strategy, Korean Journal of Financial Studies, Vol. 48, pp. 371-391.

Kim, J., and H., Lee, 2013, The Short-sales Profits of Foreign Investor, Journal of Finance \& Knowledge Studies, Vol. 11, pp. 25-49.

Lamont, O., and J. Stein, 2004, Aggregate Short Interest and Market Valuations, American Economic Review, Vol. 94, pp. 29-32.

Liu, B., and W. Xu, 2016, Short Squeezes, Working Paper, Florida State University, Available at http://dx.doi.org/10.2139/ssrn.2019361. 
한국증권학회지 제 50 권 1호 (2021)

Massa, M., and V. Beschwitz, 2015, Biased Shorts: Stock Market Implications of Short Sellers' Disposition Effect, Working Paper, Board of Governors of the Federal Reserve System, Available at http://dx.doi.org/10.2139/ssrn.2348583 .

Odean, T., 1998, Are Investors Reluctant to Realize Their Losses? Journal of Finance, Vol. 53, pp. 1775-1798.

Shefrin, H., and M. Statman, 1985, The Disposition to Sell Winners Too Early and Ride Losers Too Long, Journal of Finance, Vol. 40, pp. 777-790.

Savor, P. and M. Gamboa-Cavazos, 2011, Holding onto Your Shorts: When Do Short Sellers Retreat? Working Paper, Harvard University, Available at http://dx.doi.org/10.2139/ss rn.689162.

Stambaugh, F., J. Yu, and Y. Yuan, 2012, The Short of It: Investor Sentiment and Anomalies, Journal of Financial Economics, Vol. 104, pp. 288-302.

Woo, M., and M. A. Lee, 2019, Motivation of Short-selling in KOSPI and KOSDAQ Market, Korean Journal of Financial Studies, Vol. 46, pp. 159-186. 